\title{
Major European Stressors and Potential of Available Tools for Assessment of Urban and Buildings Resilience
}

\author{
Licia Felicioni *(D), Antonín Lupíšek ${ }^{\circledR}$ and Petr Hájek ${ }^{\circledR}$ \\ University Centre for Energy Efficient Buildings (UCEEB), Czech Technical University, \\ 27343 Buštěhrad, Czech Republic; antonin.lupisek@cvut.cz (A.L.); petr.hajek@fsv.cvut.cz (P.H.) \\ * Correspondence: licia.felicioni@cvut.cz; Tel.: +420-731-373-558
}

Received: 21 July 2020; Accepted: 9 September 2020; Published: 14 September 2020

\begin{abstract}
Recent data show that there are intensifications of phenomena related to climate change, such as the increasing of heavy rains, more frequent and intense droughts connected with fires, and alterations of the local climatic conditions, including heat islands with consequent impacts on cities, districts, and buildings. Not only are natural hazards stressing Europe but also human-induced events like low-magnitude earthquakes as a direct cause of fracking or mining. This study aimed to investigate the significant stressors and summarize what impact is the most dangerous in each European country. There is a need to secure the operating conditions of urban infrastructures and to preserve a high-quality indoor environment of buildings. The main scope of this paper is to compare selected tools that evaluate the urban and building resilience and to assess their suitability, based on an analysis of natural and human-induced hazards in the European countries. The results represent a contribution to urban and architectural planning practice, and to the consistent implementation of measures to improve the resilience of the built environment by providing guidance as to which assessment tool is most suitable for each country.
\end{abstract}

Keywords: European threats; building resilience; human-induced hazards; natural hazards; resilience assessment tools; seismicity; urban resilience

\section{Introduction}

Changing of the environmental conditions on the Earth is a natural and everlasting process. Human living conditions are modified —and as a consequence, biodiversity is irrecoverably altered. This process was in previous periods prolonged, enabling consecutive adaptation of life forms (including humans) to improve environmental conditions. Recently, the pace of transition has been accelerating.

According to the data reported by the Intergovernmental Panel on Climate Change (IPCC) [1] and by the National Aeronautics and Space Administration [2], it is clear that there are intensifications of phenomena related to climate change (CC), such as changing precipitation patterns including intense rainfalls, more frequent and severe droughts, and alterations of the local climatic conditions, including heat islands with consequent impacts on cities, districts, and buildings.

Due to the increased occurrence and concentration of extreme events related to climate change, it is essential to systematically focus on risk managing and mitigation and on improving the resilience of urban areas and buildings to reduce their vulnerability to extreme events, rather than working in just a reactive mode responding to particular events [3]. The current focus on climate change and its impact on social and economic development is also helping to accelerate recognition that natural disasters are a critical hazardous factor for the health, safety, and productivity of occupants of buildings [4], and for the sustainable wealth of the urban population. Hence, it is essential to 
develop and strengthen the built environment to create more resilient communities, protecting human lives and property against disaster cases [5]. Additionally, the risk of extreme events creates a new challenge for urban and building planners, because these problems span among scales-city, county, country [6,7]—and inappropriate building design and construction that would not be adopted to the new conditions would unnecessarily endanger the population and its assets. There arises a question: what is the right balance between the architectural planning for lower environmental impacts and the plan for increased resilience? In some cases, improved robustness or redundancy leading to increased environmental impacts at the construction stage brings benefits that become fully evident only later during the buildings' operation in terms of extended service life. Such a debate shall be a part of planning for (overall) sustainability.

The issue of resilience is embodied in the Sustainable Development Goals (SDGs) introduced in 2019 [8]. The European Handbook for SDGs [9] promotes, in Goal 13, a better knowledge of all the essential elements that can improve the understanding of disasters risk resilience, and contribute to sustainable growth. The purpose of this paper is to offer an overview of the significant stressors related to natural hazards (including climate change) and their trends in Europe, and give recommendations for developing specific regional tools for managing building and urban resilience.

\subsection{The Resilience of the Built Environment}

Much research focused on the resilience of ecological systems started in the 1970s, and has recorded remarkable growth in the last few decades, due to the environmental problems that the world has to face every day, particularly the significantly increased amount of natural disasters [10].

The current concept of resilience is indicated by a globally notable increment in interest: countries are trying to face the problem of climate change, a gradual process that can be measured and its impact relatively accurately foreseen, as shown the 2018 IPCC's report [1,11,12]. However, disasters, such as floods, also deserve more attention, because they may cause a series of losses (e.g., financial deficits, housing collapses, and casualties) [13]. Resilience enhancement features are often directly linked to the specific sector [14].

Different scales are used to measure resilience-from a single building to the urban, community, municipal, and national levels. Different actions vary according to these scales. At the building level, for example, resilience would include the capacity to manage shocks and avoid the impact of stressors; a more in-depth focus on the building resilience can be found in the Appendix A. At the urban level, in addition to these, resilience includes the capacity to manage stress or avoid a shock, and restore services and repair damages to infrastructures or buildings.

There is not any single widely accepted standard definition for urban resilience, and Appendix B provides a sample of existing definitions. This paper considers resilience as the ability of a system, entity, community, or person to adapt to a variety of changing conditions, to withstand shocks while still maintaining its essential functions, and recovering all features of the system to pre-disaster level. The sense of improving building resilience at the city level has been seen in connection with disaster risk reduction; moreover, combined with urban resilience strategies, it is possible to lead a driving force for future urban policies. Urban resilience policies require accessible and multidisciplinary planning for the future, which expects the participation of various stakeholders and experts of the field [15].

In any case, resilience as such is a part of overarching sustainability. It is influencing all the three pillars of sustainability (economic, environmental, and social), because the impacts of geophysical phenomena, including climate change and different kinds of natural and human-made disasters, affect all three pillars of sustainability. Thus, a focus on environmental resilience, social resilience, and economic resilience and their mutual interaction is essential.

The tools for evaluating resilience, described in the following paragraphs, are multi-criteria scoring systems that provide the designer with some guidelines aimed at orienting, ex-ante, and evaluating, ex-post, the technical choices used. The pre-disaster phase includes mitigation and preparedness 
actions, although the post-disaster stage is geared to response and recovery. Adaptation is usually a long-term process that takes place both before and after the disaster occurrence.

\subsection{Objective and Scope of the Study}

The main objective of the present manuscript is to compare selected tools that evaluate the urban (RELi [16] and Envision v3 [17]) and building (Resilience-based Earthquake Design Initiative (REDi) [18] and Environmentally Friendly Resilient Residential Buildings (RESBy) [19]) resilience and to estimate their suitability for resilience assessment based on an analysis of natural and human-induced (HI) hazards in European countries and, in the end, giving recommendations about which resilience assessment tools can be more suitable for each European state. Extreme events in Europe were analyzed considering three essential hazards: seismicity, floodings, wildfires, and their relative trends.

\subsection{Natural and Human-Induced Hazards}

At present, more than half of the world's population lives in cities. It is expected that, by 2050 [20], up to $75 \%$ will do so, because of growth in both people and urbanization [21,22]. As the population and number of natural disasters grow (see Figure 1), the impact of natural disasters on humans will increase too. The continuously growing extent of impacts affecting increasing population leads to costlier and deadlier accidents around the world. These problems mean that there is an ever-increasing need for attention to the risk mitigation and the adaptation of urban systems.

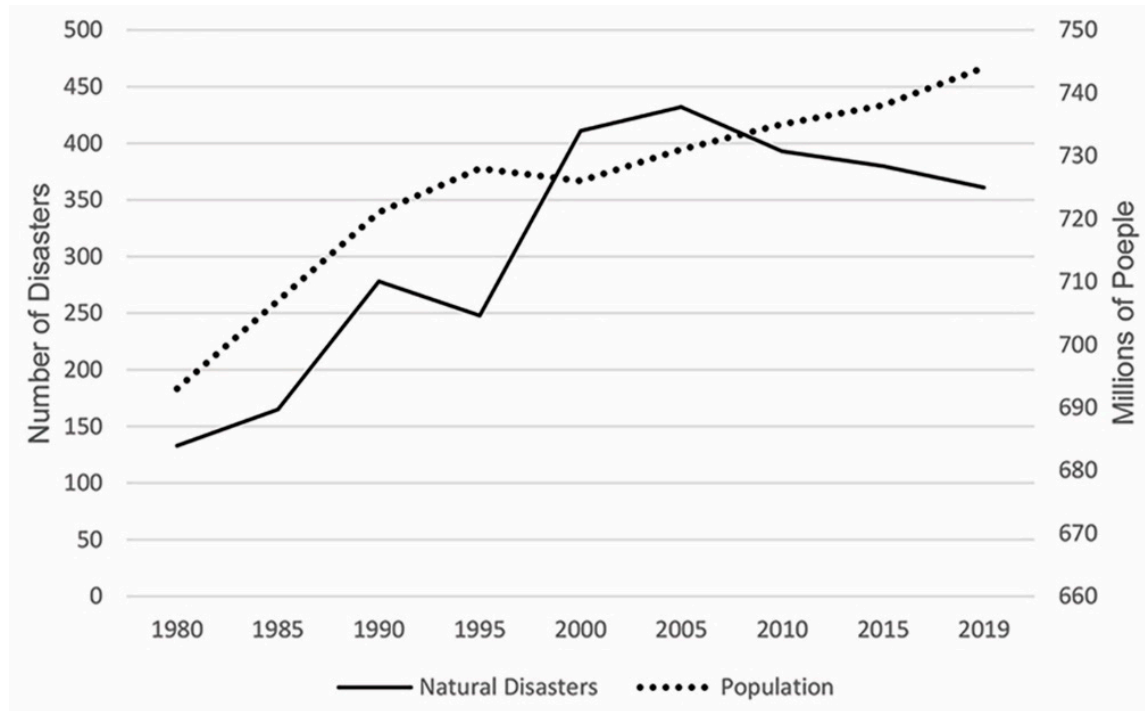

Figure 1. Trends of population growth and natural disasters in Europe since 1980. Source of data: European Environment Agency (EEA) and United Nations, Department of Economic and Social Affairs-Our World in Data. Visualization: Author Licia Felicioni.

It is essential to consider that these elements are both progressing, and the impact is much more severe because more people are affected. As people and enterprises increasingly concentrate in cities, they become highly dependent on infrastructure networks, communications systems, supply chains, and utility connections for their wellbeing. Moreover, an increase in the quality of living standards even in developed countries is needed; because the quality is more affected by disasters.

The 2019 WEF Global Risks annual report on global risks [23] highlights several types of natural disasters among the five main environmental hazards:

- Extreme weather events (e.g., floods, storms, etc.);

- Failure of climate-change mitigation and adaptation;

- Significant biodiversity loss and ecosystem collapse;

- Major natural disasters (e.g., earthquakes, tsunamis, volcanic eruptions); 
- Human-induced disasters (e.g., oil spills, radioactive contamination, HiQuakes, etc.).

\section{Materials and Methods}

Elsevier's Science Direct and MDPI databases were used to identify the literature on urban and building resilience in the latter years.

The search terms "urban resilience", "building resilience", and "natural disasters" yielded 142 results, unique publications from a diversity of disciplines (i.e., articles, book chapters, conference proceedings, and web pages).

The next step was a literature and reports' review, aimed at collecting data on natural and human-induced events in Europe and their related frequency and intensity. If they failed to define the term or used another scholar's definition, they were excluded from the literature, as shown in Figure 2.

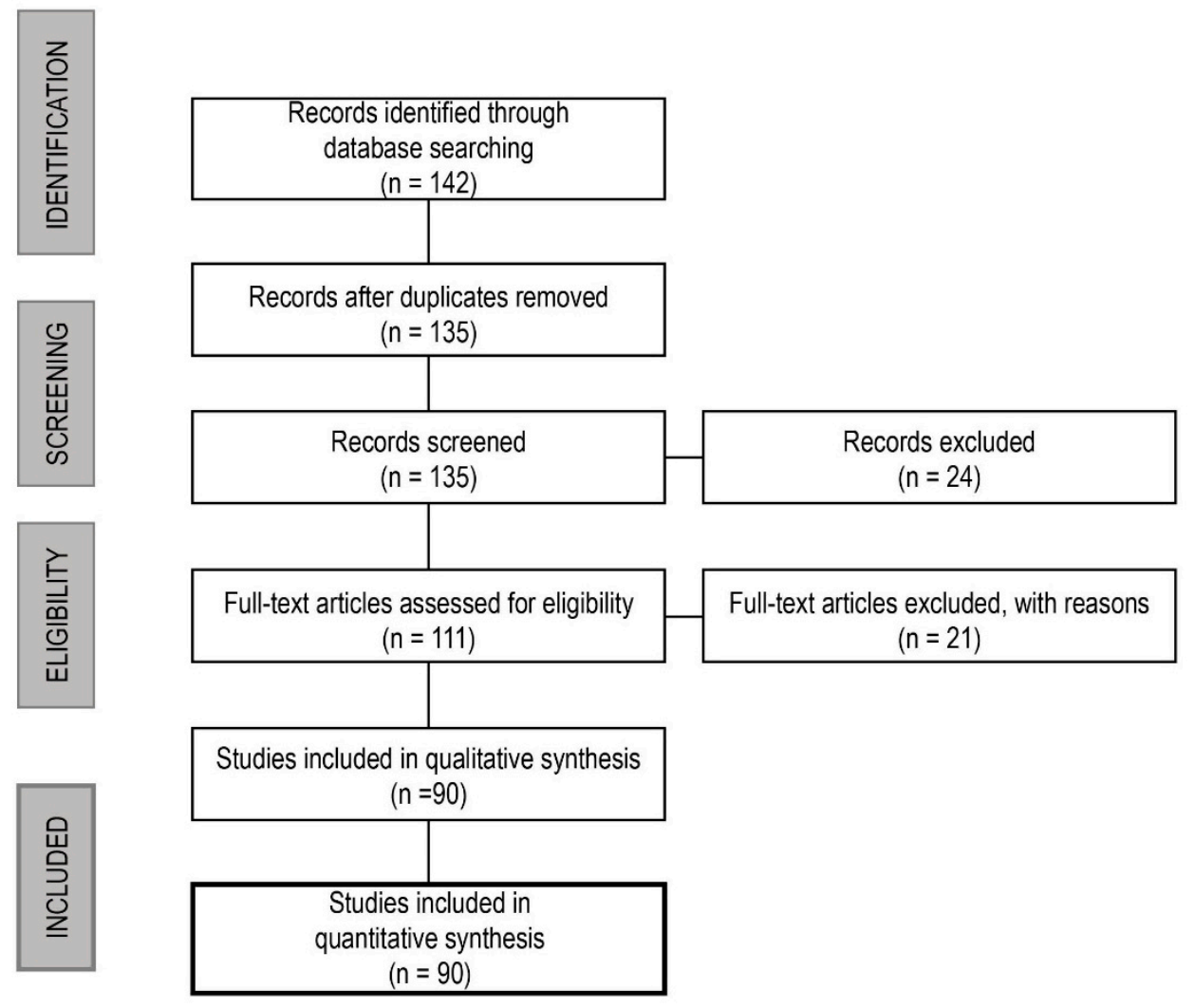

Figure 2. PRISMA 2009 flow diagram of studies considered for inclusion. Source: Author Licia Felicioni.

After, the results were visualized in maps of EU countries. Outcomes showed which areas in Europe were more affected by natural and human-induced hazards. Then, worldwide tools for urban and building resilience were selected and compared, to assess their weighting in each significant impact (floods resilience, and fire and seismic safety). As an initial point, the research hypothesis was developed, assuming that these tools have an essential role in recognizing new opportunities and setting directions for further resiliency strategies. The analysis resulted, after the evaluation and comparison of their contents, in an assessment, if they are suitable for the countries, or how they fit the specific EU country's situation.

\section{Results}

\subsection{Classification of Natural Hazards}

This paper classifies disasters according to the type of hazard that triggers them (Figure 3). There is a focus on hydrological, meteorological, and climatological events, plus geophysical 
disasters. Vulnerabilities arise for different reasons, including population growth, land-use changes, environmental poverty, urban development in risk-prone locations, and climate change [14].
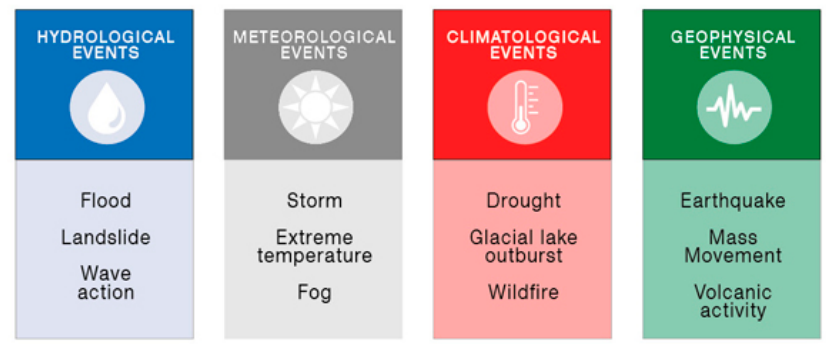

Figure 3. Classification of natural hazards. Source: Author Licia Felicioni.

\subsection{Economic Losses from Extreme Events}

The distribution losses due to natural events among the European member countries are unbalanced. The highest economic losses due to natural stressors in the period 1980-2017 in absolute terms (in order of rank) were registered in Germany (EUR 52.5 billion for floods), Italy (EUR 51.3 billion for earthquakes), and France (EUR 39.3 billion for storms) [24]. Around $62 \%$ of all economic losses [25] were a result of meteorological and hydrological events, while most victims were caused by heatwaves (Figure 4).

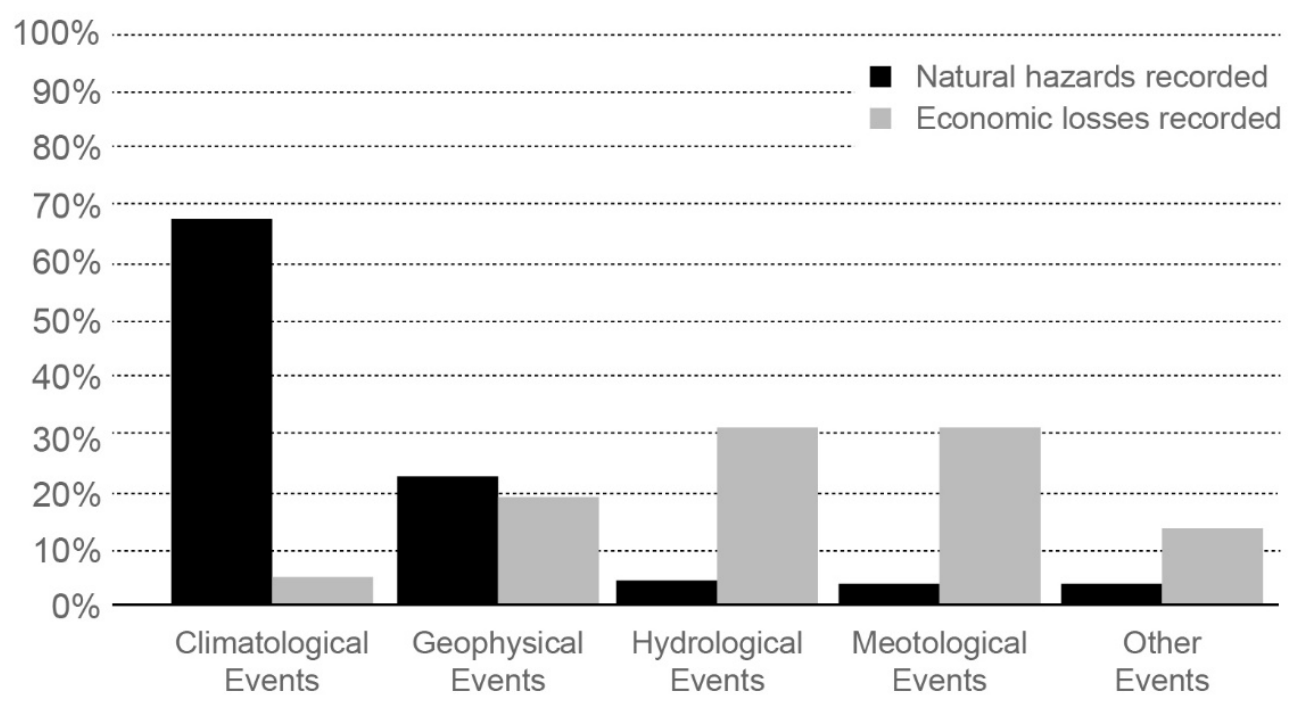

Figure 4. Percentage of natural hazards recorded in EU and EEA Member States compared to the breakdown of recorded economic losses (1980-2017). Source of data: European Environment Agency (EEA). Visualization: Author Licia Felicioni.

The highest shares of total losses in terms of cumulative gross domestic product (GDP) were registered in Croatia, Czech Republic, and Hungary [25]. According to the IPCC 2018's report [1], the increasing exposure of people and economic assets to weather and climate-related disasters has been the primary cause of long-term increases in financial losses from them. Between 1980 and 2017, the damage cost related to catastrophes for the Member States (both natural and human-made) was EUR 557 billion, and the insured losses were approximately EUR 162 billion (in 2017 values) [25].

Following this, there are a series of natural stressors that Europe must mitigate to keep the urban areas safe for human-beings and buildings. 


\subsection{Hydrological Events}

River flooding is one of the leading natural hazards occurring in Europe in terms of economic damage [9], and it is still frequently considered a direct effect of heavy rainfall [26], without considering the watershed as an interdependent system connected with the development of its territory [27].

Water management withstanding climate change and global population growth calls for technological and institutional innovation [28]. In urban and peri-urban environments, this urgency is even more evident, because they are experiencing rapid growth and continued environmental degradation all over the world [20]. As a response to this situation, [29] observed that the way decision-makers are dealing with the urban flood is changing, shifting from a strategy of resistance against flooding to a need for a change in flood management strategy, minimizing the risks $[27,30]$. An acceptable flood risk pattern has to be maintained; thus, cities must incorporate adaptation measures to allow the urban infrastructure to manage with flooding damages, considering possible future changes in hydrological events [31]. Moreover, for reducing the runoff of rainwater from the cities due to impermeable surfaces, urban environments take measures such as smart infrastructure that can address multiple issues contemporaneously. In this way, a greener, more inviting urban environment was designed, which lowers the risk of flooding and damage from drought. This is an example of a crucial step towards more resilient cities that are adequately prepared for the next future [32].

Climate change is responsible for raising existing sea levels; hence, critical flooding levels will be reached quickly and more often. The actual vulnerability in coastal areas is also influenced by socio-economic or demographic developments, such as urban sprawl, the density of the population, and the presence of physical assets/infrastructure. The risk of river flooding is projected to increase in any part of Europe by a combination of storm surges or otherwise exceptionally high sea levels. Further to climate exposure, the settlement of many new urban areas and the accumulation of assets in low-lying areas close to rivers has increased the sensitivity to floods [33].

There are different types of floods distinguished based on the source. River floods happen very often in Europe and-with storms-are the most significant natural hazard in Europe in terms of monetary damage to infrastructure, property, and agricultural land, but also casualties, with adverse effects on human health, the environment, and cultural heritage [34]. Figure 5 shows the reported flood phenomena since 1980 in Europe.

However, cities that must face the risks of coastal flooding can or already have responded by building or improving flood defenses like dams, barriers, sluices, locks, dykes, and levees, or running beach nourishment schemes, or changing land use. These resilience measures are based on information on flooding frequency, the rate of sea-level rise, and elevation, but do not include any adaptation measures, like dykes or other flood defenses, most of all during the latter years, when the floods phenomena increased, as shown the Figure 6.

Figure 6 shows that, compared to the raised average outdoor temperature, the number of floods also increased continuously. This result brings to think that climate change can detectably influence floods, as the IPCC noted in the last report [35]. Temperature is the most specific observed parameter of a changing climate system. Air temperature anomalies do not usually bring to floods because they are both controlled by large-scale atmospheric circulations and ocean interactions.

The essential factor that has to be taken into account about this impact is the soil moisture [36]. For instance, the extreme flooding in Central Europe that damaged, primarily in 2013, the south and East German states, western regions of the Czech Republic (Bohemia), and Austria, is an example of how the higher soil moisture, due to lower temperatures in winter and spring, and consequently, less evaporation, brought more massive floods for the same amount of rainfall. 


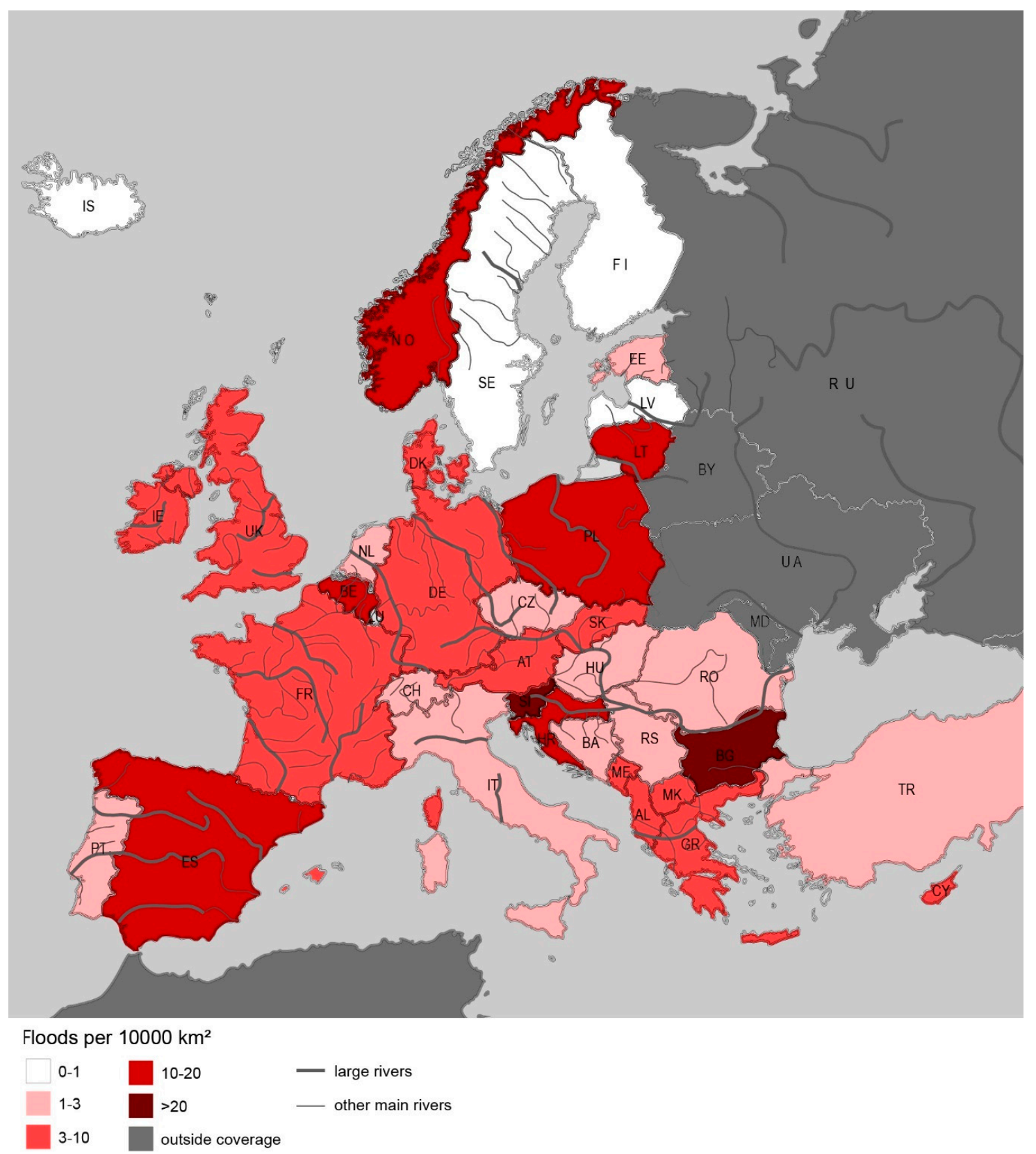

Figure 5. Floods per 10,000 km² in European countries recorded since 1980. Source of data: European Environment Agency (EEA) and Copernicus Programme. Visualization: Author Licia Felicioni.

Figure 7 shows a map with the low-lying urban areas potentially threatened by river/coastal flooding in the period between 2071-2100, but also the areas hypothetically affected by the risk of coastal flooding under an assumed sea level rise of $2 \mathrm{~m}$ and storm surge events. Among the most exposed coastal cities in Europe are many situated in the Netherlands, Germany, Belgium, and areas along the northern Italian coastlines, in particular, Venice. 


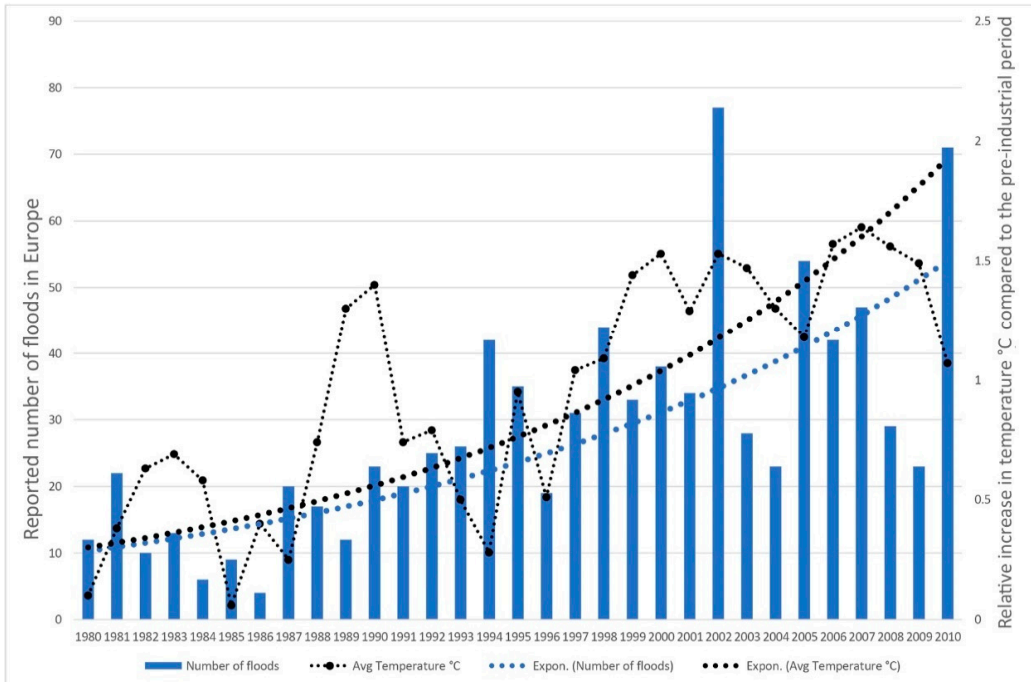

Figure 6. The trend of severe past floods (1980-2010) and temperature in Europe analyzed using EEA data related to European surface temperature relative to the pre-industrial period (average temperature between 1850 and 1900). Source of data: European Environment Agency (EEA) and the European Centre for Medium-Range Weather Forecasts (ECMWF). Visualization: Author Licia Felicioni.

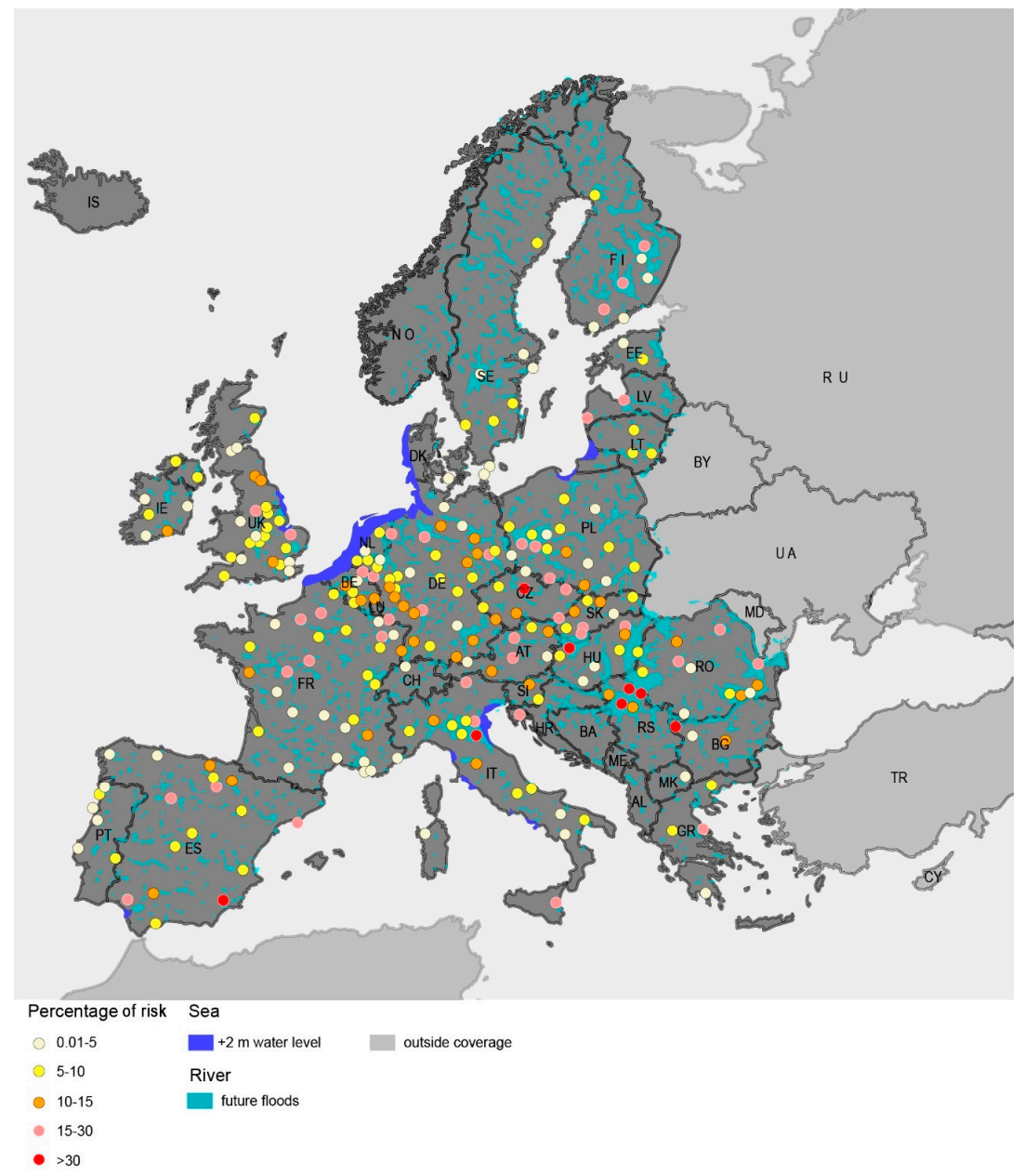

Figure 7. Percentage of the risk of flooding in European urban areas caused by rivers and by sea-level increase by $2 \mathrm{~m}$. Source of data: European Environment Agency (EEA). Visualization: Author Licia Felicioni. 
The main message that these maps shared is which hazard every EU country has to face, in order to help for understanding these stressors for enhancing urban and building resilience. Currently, Europe is in an unusual flood-rich period in term of occurrence and spatial proportions, and that brings flood-risk management strategies and assessment tools adequately focused on this impact under consideration.

\subsection{Climatological Events}

\section{Wildfires}

Fires are an integral component of the European landscapes, especially in the Mediterranean region. The hazard of uncontrolled fires is higher and higher and may cause extensive environmental and economic damages. About 65,000 fires occur in Europe every year, burning approximately half a million hectares of greenfield and forest areas [37]. The fire danger series have to be analyzed; thus, the meteorological fire danger indices were used, in particular, the Canadian Fire Weather Index (FWI) [38], which is regularly utilized to rate fire potential owing to climatic conditions. The mean seasonal FWI can explain most of the year-to-year variation in burnt areas in European countries [39]. This index is a whole number that ranges between 0 and 40 . The primary parameters needed to calculate it are [40,41]:

- The humidity of the air;

- Afternoon temperature (when the value is the highest);

- The 24-h total precipitation;

- The maximum speed of the average wind.

Past trends (1980-2010) of wildfires have been investigated (Figure 8), and the results showed considerable variability from one year to the following, which was strongly determined by the seasonal meteorological conditions. During this 30-years-period, the burn-areas exponential curve goes down, while the number of floods one increases during the whole period. The explanation of these results can be, in the case of fires, that it is possible to make some specific provisions because of the awareness of this hazard, such as mapping the protected areas and, consequently, ensuring better protection against wildfires [42]. On the other side, for floods, it is possible to make some safety barriers around the main points (rivers, sea). Still, it is much more challenging to forecast the phenomena and prepare adequate protections.

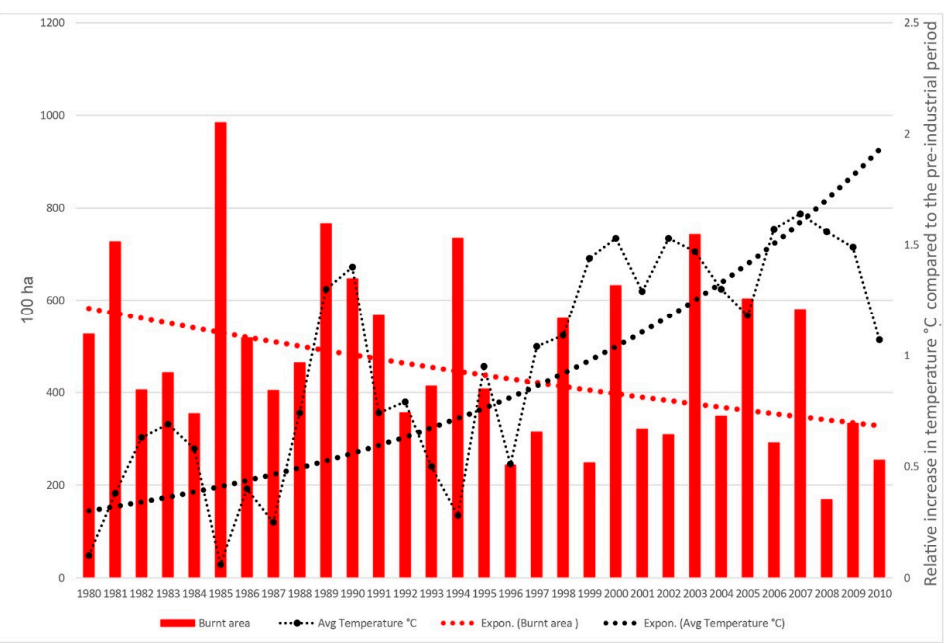

Figure 8. The trend of burnt areas (1980-2010) and temperature in Europe analyzed using EEA data related to European surface temperature relative to the pre-industrial period (average temperature between 1850 and 1900). Source of data: European Environment Agency (EEA) and the European Centre for Medium-Range Weather Forecasts (ECMWF). Visualization: Author Licia Felicioni. 
Despite a smaller overall area being burnt than in previous years, the absolute fire danger will remain highest in southern Europe, due to above-average temperatures persisting, and the increase in fire danger is projected to be mainly significant in western-central Europe (Figure 9), as a consequence of high emission scenarios that brings to more severe fire weather and substantial expansion of fire-prone areas $[43,44]$. This can create conditions that help the ignition and spread of forest fires, causing high economic and environmental losses [45,46].

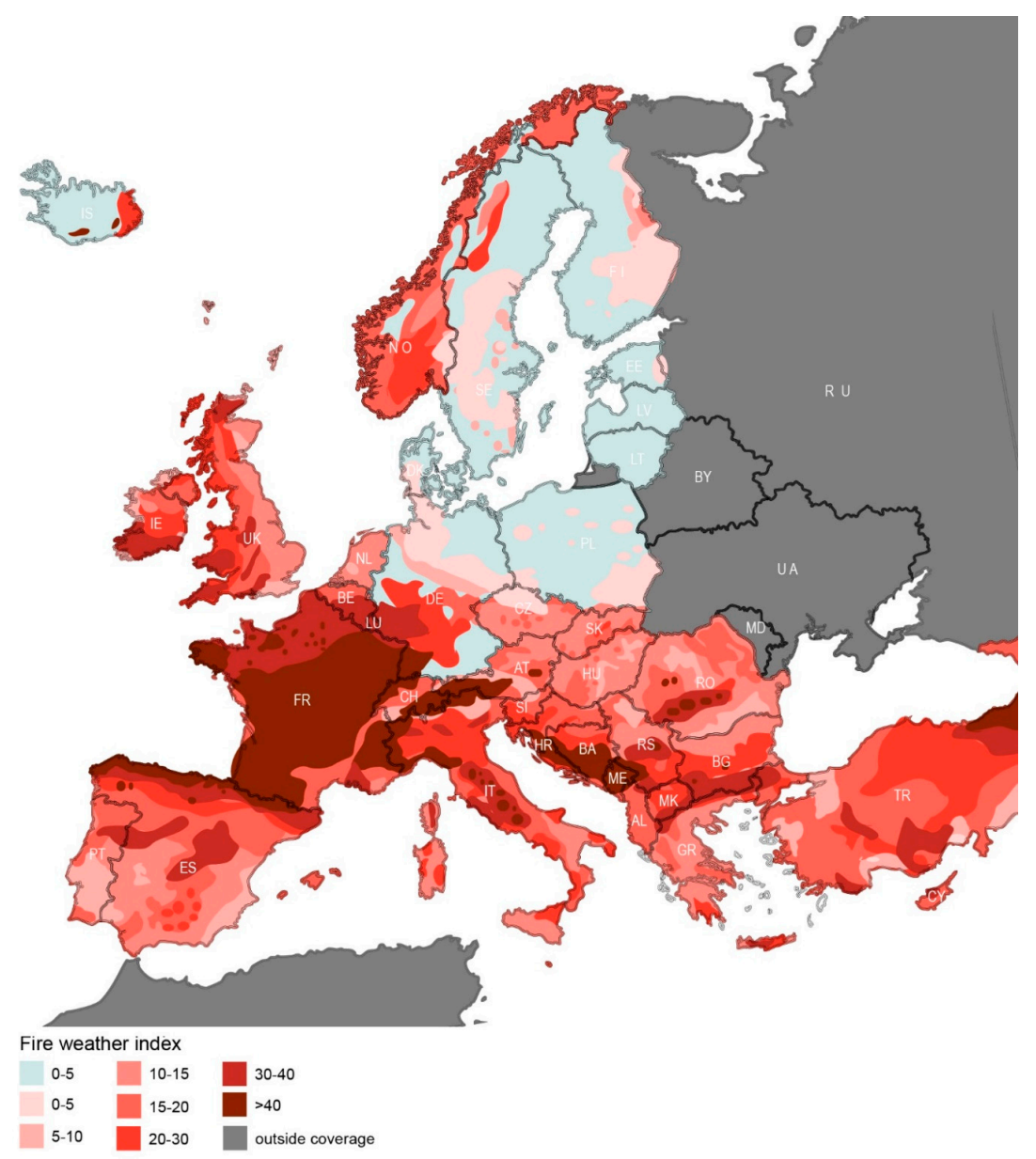

Figure 9. Weather-driven forest fire danger in the projected change scenario (2071-2100). Source of data: European Environment Agency (EEA). Visualization: Author Licia Felicioni.

Nevertheless, Portugal, Spain, and Turkey remain the countries with the highest fire hazard. Climate change projections suggest that there will be an increase of heatwave phenomena, as well as droughts across southern Europe, but it would be possible to reduce fire risks with substantial adaption measures, such as improved fire prevention [47,48].

Knowing indeed, where or when wildfires will occur precisely is not possible. However, collecting information from climate and weather patterns, historical fire occurrence (see Figure 8), projected forest fire danger (see Figure 9), and many more, it is possible to have a general overview to estimate of the likelihood of an area for a hypothetical wildfire. The European Commission has just launched the Copernicus Satellite system, which is used for preparatory and monitoring measures, and mapping forest fires emergencies [42].

\subsection{Geophysical Events}

Though climate change is a long and slowly progressive process that could be handled with constant adaptations; an earthquake is an acute shock that strikes suddenly and cannot be foreseen, 
and facing this disaster is necessarily a case of quick response and effective recovery strategies [14,49]. Green open spaces contribute to enhance climate resilience, reducing the phenomena of heat island in the urban areas. In contrast, not only green space, but also built-up and undeveloped open space, has an essential role in urban seismic resilience. Nevertheless, urban and building resilience to both climate change and seismic actions could be improved through the process of sustainable urban management, including participants' involvement [50]. Life cycle assessment (LCA) methodology represents an essential tool for sustainable structural design. Moreover, it can also result in a tool to help decision making, influencing the choice of materials and technologies, the promotion of particular design criteria, and recycling [51]. Although LCA is essential, in many rating tools, it is not adequately considered-see the analysis of the tools in Section 3.8.

\subsubsection{Natural Earthquakes}

Geophysical hazards (particularly earthquakes, tsunamis, and volcanic eruptions) differ considerably in different regions of the world. They are concentrated in major active earthquakes zones along with contacts of tectonic plates. Europe is on a large Eurasian tectonic plate, in south neighboring with the African tectonic plate. Thus, the risk of seismic activity increases along the Mediterranean coast, particularly in Italy and Greece. Northern Europe is mostly free of major earthquake zones, except for Iceland laying on the contact zone. In Figure 10, the leading natural earthquakes recorded in Europe since 1970 are shown, with their related magnitude; only the earthquakes with a magnitude higher than six have been summarized in the figure.

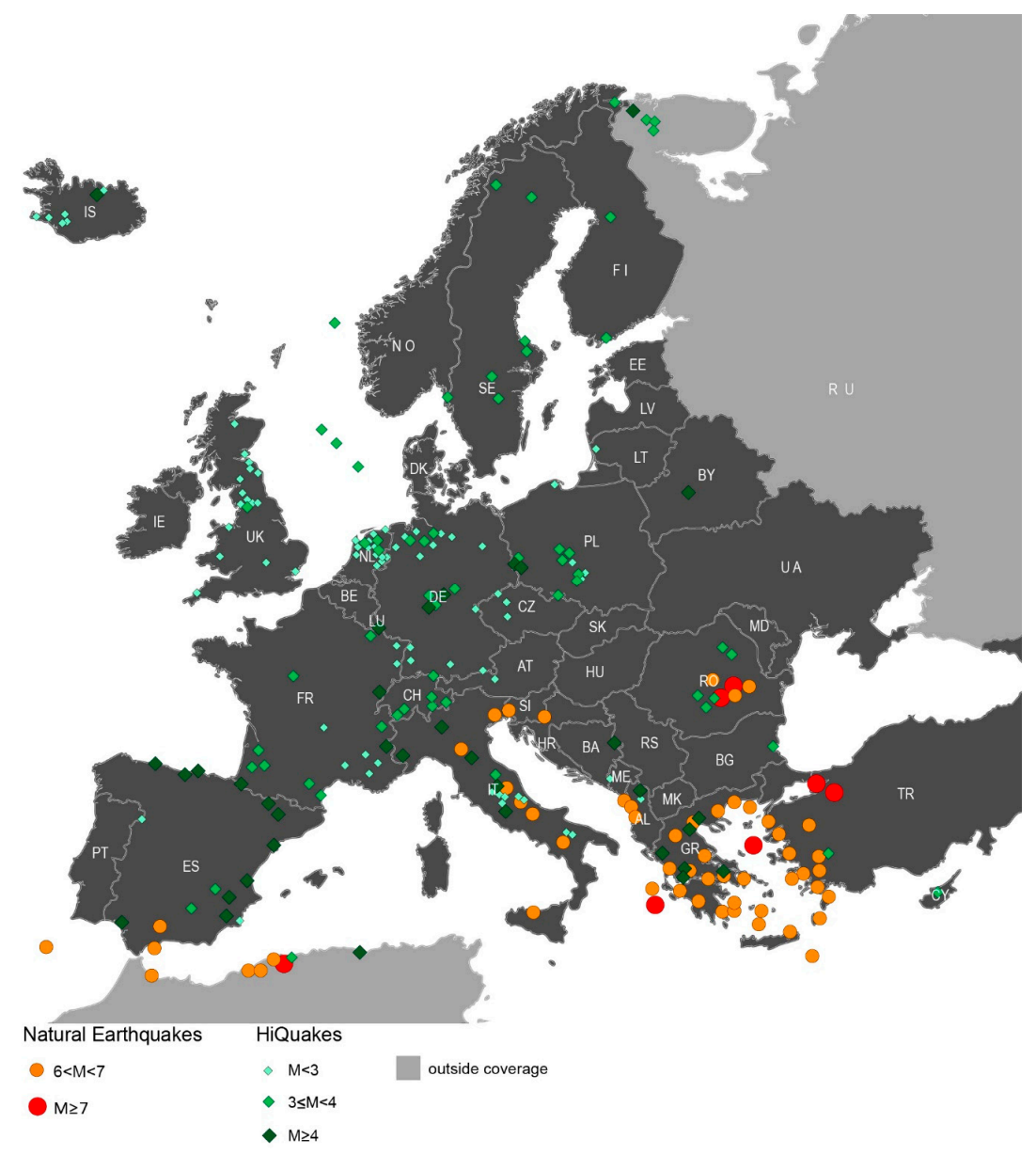

Figure 10. European map of recorded seismic events from 1970. Source of data: European Environment Agency (EEA) and the Human-Induced Earthquake Database. Visualization: Author Licia Felicioni. 


\subsubsection{Human-Induced Earthquakes}

The Human-Induced Earthquakes (HiQuakes) [52], like natural earthquakes, can present apparent hazards to buildings, infrastructure, and human life [53]. Most HiQuakes seismicity has a low magnitude, less than $3 \mathrm{M}$, as Figure 10 shows. The events are happening mainly in Northern Europe (The Netherlands and Germany), in areas where the oil and gas extraction processes are more often.

HiQuakes could be caused by geothermal operations, reservoir impoundment (water behind dams), wastewater injections, and oil and gas operations such as hydraulic fracturing [54,55]. Due to large volumes of fluid injected into underground formations for storage or disposal, some fluid may move into faults causing pressures and releasing stored energy. This can generate seismicity and possibly an earthquake. In the literature, there is a difference between "induced" and "triggered" seismicity, based on how the energy is caused; the term "induced" is used when most of the energy is made by anthropogenic origin meanwhile the term "triggered" is used when the cause is natural [56].

\subsection{Threats Summarization}

Figure 11 shows a summary of the European threats and the countries that are highlighted by the previous figures. Following these figures, the table considers every state, and for each, it is assigned a black dot for the major recorded shocks and a bigger red one for the most frequent and aggressive problem; the blank space means just that some threats do not happen so often, but not that the country has not to face them. The comparison of these impacts in the European scenarios indicates that southern Europe suffers more for seismic hazard (Italy, Greece), northern Europe for human-induced earthquakes (The Netherlands). Meanwhile, Central Europe has the flooding problem (Germany, Czech Republic, and The Netherlands). In the last decade, the droughts problem became to be extremely important around Europe.

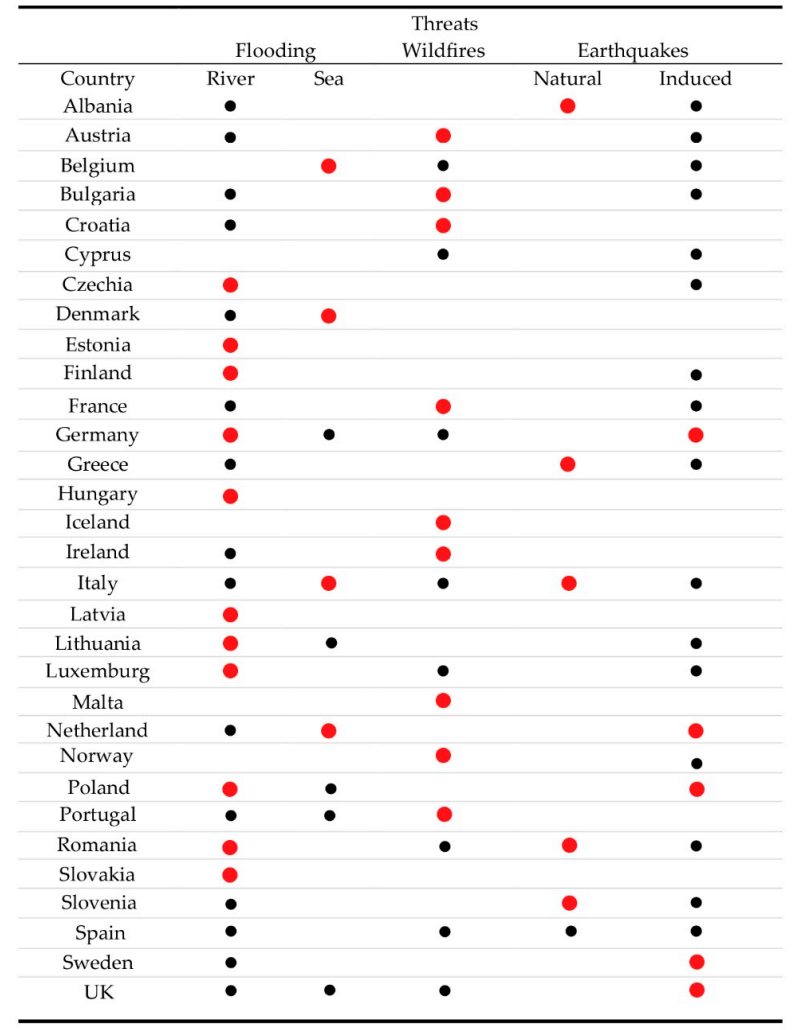

Figure 11. European major threats and countries related. (Black dots for major recorded shocks, big red dots identify the most frequent stressors, blank spaces indicate that those threats do not happen so often in the country). Source: Author Licia Felicioni. 


\subsection{Resilience Evaluation Tools}

As a result of the increasing amount of shocks previously described, cities are responding in a wide variety of ways [57]. The importance of developing strategies for improving the resilience or minimizing negative impacts caused by unexpected disruptive events has been recognized and broadly accepted, and many tools have been developed worldwide [58]; the U.S. Green Building Council, administrating the Leadership in Energy and Environmental Design (LEED) certification, made resilience a policy priority, writing RELi, a tool entirely focused on resilience.

Resilience tools can be suitable for an extensive range of stakeholders, but it can be tough to find the proper tool for the job. It is essential to focus on the regional level while choosing the appropriate tool. Currently, European countries are developing guidelines [59] suitable for facing those hazards, such as the Risk Systemicity Questionnaire [60] and the Resilience Maturity Model [61,62], just two of the H2020 funded projects. The Risk Systemicity Questionnaire aims to support cities by enhancing their risk assessment through an advanced focus on the interactions between different types of risks that are evaluated within ten main topics (e.g., climate change air pollution and flooding). On the other hand, the Resilience Maturity Model enables cities to assess their maturity stage and to find policies to permit the city to evolve and move to a more resilient way. Moreover, building sustainability certification systems like Building Research Establishment Environmental Assessment Method (BREEAM) [63] or the Deutsche Gesellschaft für Nachhaltiges Bauen (DGNB) [64] also have some criteria focused on resilience enhancement. Still, their weighting is very light compared to their other topics.

Thus, the paper analyzed some resilience assessment tools that are now used mostly in the United States for enhancing properly urban and building resilience. The aim is to give some recommendations on how to develop new future resilience assessment systems, because regions, cities, and even communities are more-and-more called on to act at their local scale. In fact, for achieving the Sustainable Development Goals (SDGs) of the European Union [9], the right tool has to be considered, because different countries and different regions have different conditions. It is crucial to tailor the review to local situations and challenges. For instance, in Central Europe, the main problems are floods and droughts, and, more recently, the UK has had to face storms and heavy rain.

In Italy, the primary stressor is the seismic hazard but the Italian rating system, Protocollo ITACA [65], does not consider at all this risk, it is more focused more on a building's energy efficiency, instead of a building's robustness.

\subsection{Urban Resilience Tools}

\subsubsection{RELi 2.0}

RELi [16] combines a comprehensive and expandable action list with an integrative process for developing next-generation communities, neighborhoods, buildings, homes, and infrastructure. RELi is a rating system that works in cooperation with LEED [66] to tackle extreme events and stressors, like global warming, sea-level rise, social and economic volatility, and resource shortages [67]. The Resilience Action List Credit Catalogue (Figure 12) includes over 190 indicators referred to LEED credits and to 2030 Palette [68], a free online platform that sets the principles behind carbon neutral and resilient built environments. Still, there is also a strong emphasis on resilience and sustainability. It is highlighted that the design method is an integral part of achieving high-performing, resilient design outcomes [69]. Figure 12 shows the weighting for each of the eight categories of the RELi resilience assessment tool.

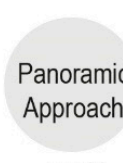

$7.7 \%$

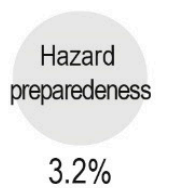

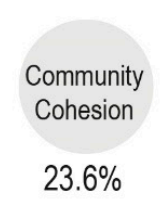

$23.3 \% \quad 23.6 \%$
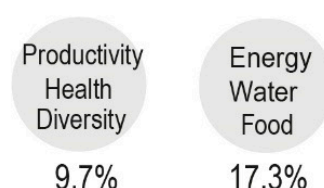

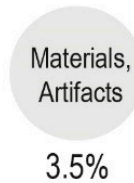

Figure 12. RELi assessment categories and their relative weightings. Source: Author Licia Felicioni. 
Hazard mitigation with criteria like fundamental/advanced emergency operations, and community cohesion with community connectivity, are the areas more influent in the whole system. RELi also acts directly on extreme weather, wildfire, and natural and human-made earthquake within the hazard mitigation category. It asks to meet some requirements like National Fire Protection Association (NFPA)for fires prevention [70]. The RELi method is very user-friendly: the criterion is presented with an intent (the aim of the criterion) and requirements (what it should be done to gain the criterion's points). For accomplishing these requirements, there are usually different ways that can be followed; then it is necessary to certify that the goal has been met with documents that prove it; precisely the same pattern of LEED certification. Moreover, as the LEED rating system, also RELi considers the life cycle assessment (LCA) of the materials in the prerequisite MA 1.0: minimum material effectiveness + life cycle planning. According to the criteria, it is necessary to consider the environmental product declaration (EPD) and the life-cycle stages for comparing every product and choosing the most suitable.

\subsubsection{Envision V3}

Efforts to combine resilience indicators with sustainability in the United States had already started with the adoption of RELi resilience credits [16] in Envision V3 [71]. The Envision ${ }^{\circledR}$ Protocol is the first rating system to create sustainable infrastructures through an analysis grid, adaptable to any infrastructure development project. Envision provides guidelines on sustainable best practices to users and serves not only as a design tool but also for evaluating infrastructure projects once completed $[17,72]$.

Developing a framework for sustainability and urban resilience means that they collectively provide a more comprehensive understanding of the issues. The holistic/integration process takes deep consideration of the location, climate, and type of natural hazards in different geographic areas (Figure 13) [67].
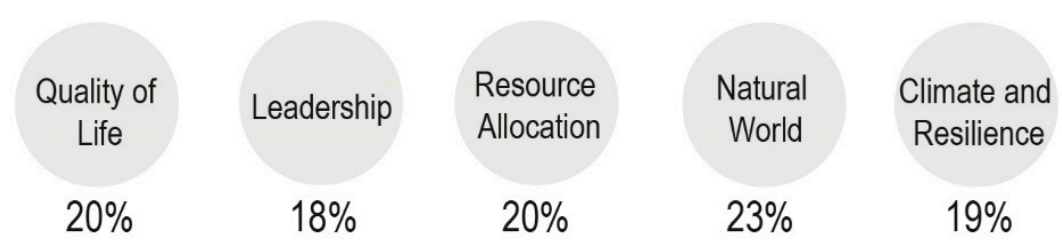

Figure 13. Envision v3 five main areas and their weightings. There are 1000 available points available among 64 different credits. Source: Author Licia Felicioni.

Minimizing emissions and consequently face climate change and other risks (such as flooding or fires) for ensuring the resilience of infrastructures is the main scope of the climate and resilience category ( $19 \%$ of weighting among the tool-10 credits).

For instance, the CR2.3 Evaluate Risk and Resilience credit requires a comprehensive risk evaluation to understand potential hazards/threats and the project's vulnerability. For example, flooding might be a hazard to a project; critical structures located below flood levels would be vulnerable to that threat. An evaluation of the flood event's probability and severity as a factor of the related losses is needed if the critical systems were flooded. Therefore, Envision is required to determine the associated consequences of the occurrence in each sustainability category of social (people, community), environmental (contamination, destruction), or economic (cost of repair, financial losses). Sixty-four non-mandatory criteria characterize the Envision method. Each criterion presents the following parameters:

- Total possible points;

- Intent (the credit's goal);

- Metric (how the credit will be measured); 
- Level of achievement (description of the requirements required to meet each level of achievement); typically, there are five different levels (improved, enhanced, superior, conserving, and restorative) that indicate how much the credit is addressed and consequently how many points will be released;

- Description of the criterion;

- Performance improvement (performance benchmarks set);

- Criteria evaluation and documentation (what kind of documents have to be submitted to demonstrate that requirements were met).

Moreover, within Envision v3, it is fundamental to take into account a life-cycle economic approach for enhancing decision making by encouraging the effective management of resources and assessing that ultimately lead to more sustainable and resilient projects. The LD3.3 Conduct a Life-Cycle Economic Evaluation credit (max 14 points) aims to conduct a life-cycle cost analysis (LCCA) on the whole project to identify the total economic impacts of the project.

\subsubsection{Comparison between Urban Resilience Tools}

In Table 1, it is shown the comparison between RELi and Envision, tools both developed in the USA but starting to be used worldwide for evaluating urban resilience.

Table 1. Comparison between urban resilience rating systems.

\begin{tabular}{|c|c|c|}
\hline & RELi 2.0 & Envision v3 \\
\hline Developer & USGBC (2018) & $\begin{array}{l}\text { Institute for Sustainable Infrastructure (ISI) } \\
\text { and Zonfnass Program for Sustainable } \\
\text { Infrastructure (Harvard University) (2015) }\end{array}$ \\
\hline \multirow[t]{4}{*}{ Who is it for? } & Owners & Owners \\
\hline & End Users & End Users \\
\hline & Planners & Planners \\
\hline & & Government \\
\hline Maturity & Emerging & In use \\
\hline Number of credits & 43 & 64 \\
\hline $\begin{array}{l}\text { Maximum total points in the } \\
\text { framework }\end{array}$ & 800 & 1000 \\
\hline Credit categories & 8 & 5 \\
\hline Costs & USD 1200 (GBCI members) & $\begin{array}{l}\text { The Envision sustainability framework is } \\
\text { free for all ISI members. Open Source }\end{array}$ \\
\hline Award Levels & $\begin{array}{l}\text { USD } 1500 \text { (non-members) } \\
300 \text { points-Certified } \\
350 \text { points-Silver } \\
450 \text { points-Gold } \\
600+\text { points-Platinum }\end{array}$ & $\begin{array}{l}20 \% \text { credits-Verified } \\
30 \% \text { credits-Silver } \\
40 \% \text { credits-Gold } \\
50 \% \text { credits-Platinum }\end{array}$ \\
\hline
\end{tabular}

Behind this more generic information, the main difference between these tools is that RELi has a broader background on hazards. For instance, it considers more seismic safety (28.1\%) than Envision, which has the same weighting for facing each stressor (2.3\%).

\subsection{Building Resilience Tools}

\subsubsection{REDi}

The aim of Resilience-based Earthquake Design Initiative (REDi ${ }^{\mathrm{TM}}$ ) [73] Rating System, developed by ARUP, is to provide stakeholders with a framework for implementing a "resilience-based earthquake design". These planning and assessment approaches are within a holistic process that identifies and mitigates earthquake-induced risks, to enable quick recovery of the buildings. The framework is developed by four main steps, as Figure 14 shows. 


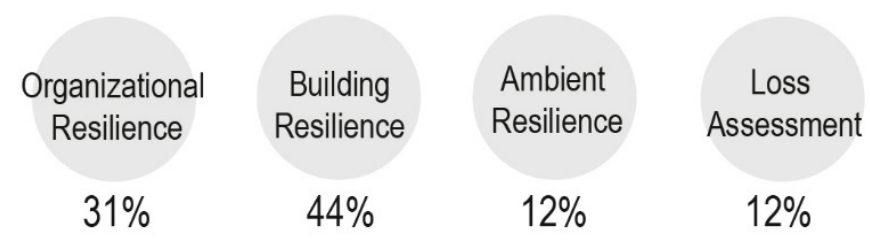

Figure 14. Resilience-based Earthquake Design Initiative (REDi) framework and its related four categories weightings, 65 criteria available within the tool. Source: Author Licia Felicioni.

Sixty-five non-mandatory criteria characterize the REDi method. Compared to the other analyzed tools, it is the only one that does not work with a points system; in fact, its rating is assessed by three different factors: downtime, financial loss, and occupant safety (Table 2). Each main category (organizational, building and ambient resilience, and loss assessment) has its criteria, which have other subcriteria that address the satisfaction of the requirements for meeting the rating. For each credit, standards requirements have to be pursued, such as enhancing the structure or the resuming of building operation after the hazard. One of the critical aspects of resilience-based design is preparedness for post-earthquake recovery to ensure continued operation and livable conditions immediately after the extreme event $[18,74]$.

Table 2. REDi thresholds according to three key aspects (downtime, financial loss, and occupant safety) after a shock occurred. Source: REDi, 2013.

\begin{tabular}{ccccc}
\hline Rating & \multicolumn{2}{c}{ Downtime } & Direct Financial Loss & Occupant Safety \\
\hline Silver & $<6$ months ${ }^{1}$ & $<6$ months $^{2}$ & $<10 \%$ & Injuries possible \\
Gold & Immediate $^{1}$ & $<1$ month $^{2}$ & $<5 \%$ & Injuries unlikely \\
Platinum & Immediate $^{1}$ & $<72 \mathrm{~h}^{2}$ & $<2.5 \%$ & Injuries unlikely \\
\hline \multicolumn{5}{c}{}
\end{tabular}

This tool is handy for seismic resilience mostly ( $40 \%$ of its criteria); in fact, also in RELi, it is used as a guideline for safety measures. On the other hand, it does not treat further hazards properly, but just the threats that are consequences of an earthquake event (3.1\% of its criteria about fire). For example, in the category ambient resilience, in the criterion C3.1.5-Assessment of Surrounding Buildings, the assessment should include qualitative external falling evaluation hazards and fire hazard. At the same time, also in the building resilience category, the floods are treated as a consequence $(1.5 \%$ of its criteria) of storm surge or tsunami and in this way, are given some guidelines for avoiding building electrical system in the lower level.

\subsubsection{RESBy}

Environmentally Friendly Resilient Residential Buildings (RESBy) was developed in 2017 by the University Centre for Energy Efficient Buildings (UCEEB) of Czech Technical University in Prague. One of the main objectives of RESBy is the development of a methodology for the evaluation of new buildings in the planning phase for resilience, climate change mitigation, and adaptation, with a focus on Central European residential buildings [19]. The list of criteria that have equal weights is shown in Table 3. For evaluating the potential threats for residential buildings, it is developed this assessment method that provides descriptions of indicators, procedures for calculation of the values, and benchmarks for calculating the score for each criterion [75]. Dislike REDi, the RESBy tool does not consider seismic issues, as, in Central Europe, the occurrence of earthquakes is rare and very weak. From the other categories of hazards of concern, the method evaluates means of local mitigation of flash floods, minimization of damage from regular floods, resilience to extreme weather events, and protection against wildfires. In addition to these, the method also assesses the level of preparedness for buildings' operation in case of infrastructure failures resulting from disasters. 
Table 3. Set of criteria for the assessment of the resilience of multifamily residential building in Central Europe.

\begin{tabular}{|c|c|}
\hline Category & Threat \\
\hline \multirow[t]{5}{*}{ Climatic and atmospheric threats } & Torrential rains Floods \\
\hline & Extreme summer and winter temperatures \\
\hline & Longer periods of drought \\
\hline & Heat islands \\
\hline & Dust particles in outdoor air \\
\hline \multirow[t]{2}{*}{ Fire } & Effects of external fire \\
\hline & Effects of indoor fire \\
\hline \multirow[t]{2}{*}{ Noise } & Noise from transportation \\
\hline & Noise from external technological sources \\
\hline \multirow[t]{4}{*}{ Social threats } & Ageing population \\
\hline & Low architectural and operating quality, low variability \\
\hline & Energy poverty \\
\hline & Disorderly conduct, Social riots and Crime \\
\hline \multirow{4}{*}{ Infrastructural failures } & Interruptions of electricity supply for more than several hours \\
\hline & Interruptions of supply of heat or gas for heating for more than several hours \\
\hline & Interruptions of freshwater supply for more days \\
\hline & Interruptions of fuel supplies for more weeks \\
\hline Risk of failures of building services & Unreliability or over-complexity of building services \\
\hline
\end{tabular}

The criteria were developed in 2018, according to projections of the future climate in Central Europe based on the literature [76]. As the previous European maps showed, the most frequent hazard in Central Europe is the floods. In this way, this tool considers many measures to avoid this building's potential threat. One limitation of this system is that it is suitable just for new residential buildings.

\subsubsection{Comparison between Building Resilience Tools}

About building resilience, both tools consider the three considered impacts. REDi has criteria for facing floods and fires, even if it is more focused on seismic safety. Instead, RESBy has several measures for tackling floods and fires; moreover, it takes also into account measures for facing droughts. Seismic resilience is not considered in this tool because it is developed in the Czech Republic, a non-seismic hazard country.

In Table 4, the comparison between REDi (USA) and RESBy (Czechia) is shown.

Table 4. Comparison of building resilience rating systems.

\begin{tabular}{ccc}
\hline & REDi & RESBy \\
\hline Developer & ARUP (2013) & UCEEB (2017) \\
Stakeholders & Owners & Owners \\
& End Users & End Users \\
& Planners & Planners \\
Region & Worldwide & Central Europe \\
Maturity & Emerging & Developing \\
Number of credits & 65 & 20 \\
Maximum total points in the framework & - & 200 \\
Credit categories & 4 & 6 \\
Costs & Open Source/Freemium & Freely available \\
Award Levels & Silver ${ }^{1}$ & Under development \\
& Gold ${ }^{1}$ & \\
\hline
\end{tabular}

\footnotetext{
${ }^{1}$ According to downtime, financial loss and occupant safety.
} 


\subsection{Comparison between Resilience Assessment Tools}

For a general comparison, as the Figure 15 shows, the RIBA Plan of Work [77] was used, a document that outlines all stages in the planning, design, and building process, from conception to completion on site. Envision is the tool that covers almost all the whole life cycle of the infrastructure.

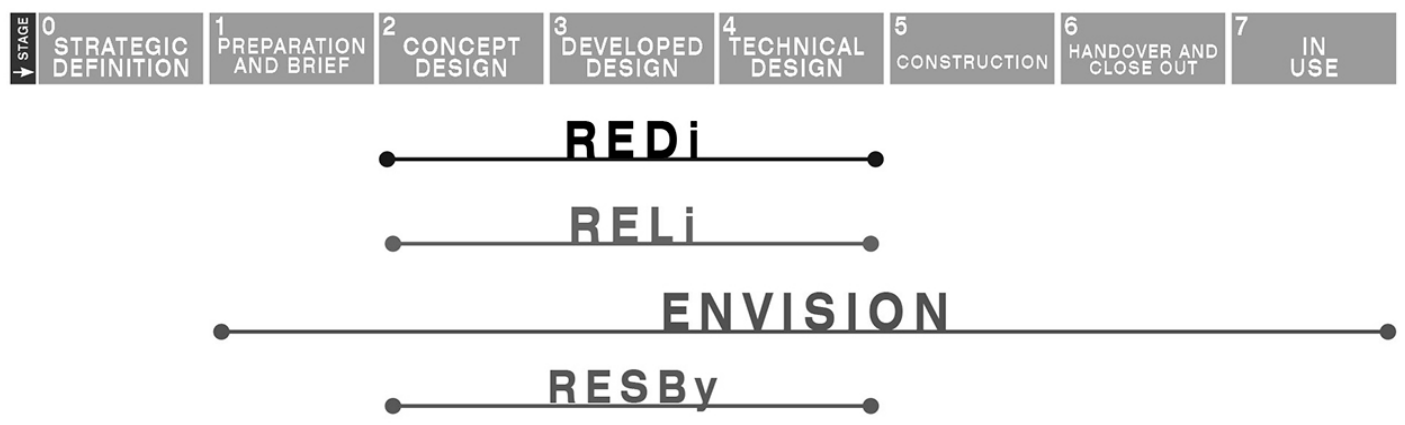

Figure 15. The RIBA Plan of Work 2013. Source: Author Licia Felicioni.

On the other hand, Figure 16 shows the comparison between the analyzed resilience assessment tools and other international rating systems about their weightings for the significant European threats (floods, forest fires, droughts, and earthquakes). The popular rating systems, such as LEED or DGNB, present some criteria for hazards facing (e.g., sensitive land protection in LEED's location and transportation category [78] for floods, or local environment in DGNB's site quality category [79] for floods and forest fires). Even though they are considered in the framework, they are not specific enough to give sufficient guidelines for enhancing resilience; only about $5 \%$ of their criteria (for both LEED and DGNB) can cover such hazards. On the other hand, these sustainable tools are used mostly in different topics such as energy optimization or decarbonization; in fact, $28 \%$ of LEED criteria and almost $19 \%$ of DGNBs' ones are about energy savings.

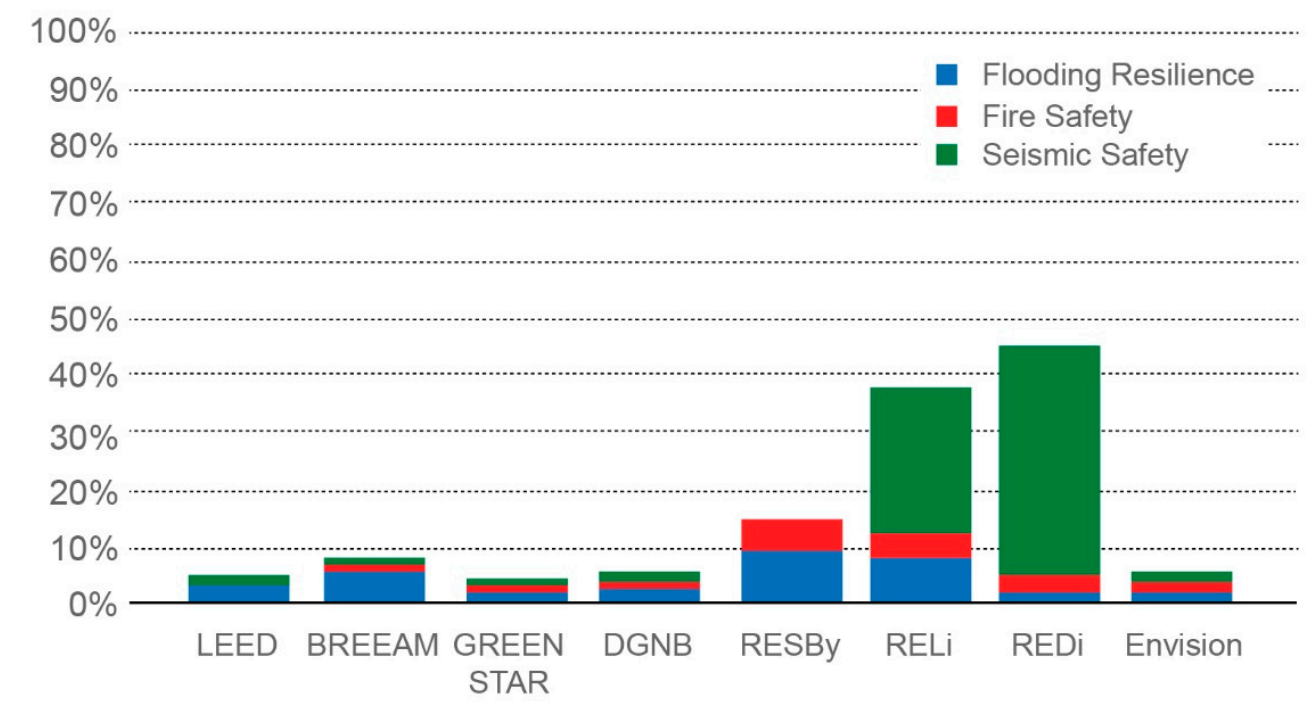

Figure 16. Comparison between international rating systems and resilience assessment tools. Source: Author Licia Felicioni.

\section{Discussion}

Resilience is seen as an essential characteristic of the built environment that helps to reduce the vulnerability of citizens to weather-related hazards. In the presented maps, different risks in different European countries, and some related tables with the recorded frequency since 1980 are shown. 
Selected tools covering resilience were analyzed, but they were developed for specific situations in some countries, and are not applicable to other states. The target of this analysis was to identify how the European countries can mitigate the threats. Each area is affected by different hazards, so each country should have, in a specific rating tool, the criteria for the assessment of these particular relevant impacts like floods, earthquakes, HiQuakes, droughts, and many more. It cannot be covered by a unified general system, which cannot sufficiently address all specifics of the country and its regions. On the other hand, these tools are not appropriate to solve all the problems in the country because, as Figure 16 shows, they have different weightings for each impact. The proper location-contextualized weighting is a topic for further research in the field.

Now, according to the previous maps and the analysis of the tools, it could be possible for the stakeholders, such as city and urban planners, to find the right balance between lower environmental impacts and urban resilience in the paradigm of smart cities. A smart city is a consequence of smart planning that has resilience as one of its principal aims [80]. For instance, smart planning can encourage resilience and river flood protection with shields or disposition of the building installations on the higher floors but, at the same time, gives guidelines to minor adjustments, such as rain gardens on the streets for slowing runoff and consequently avoiding the paralysis of the sewer systems. These urban strategies will not only provide a more resilient urban environment, but they will also enhance spaces more pleasantly and attractively for the community. The challenge now is to measure the state of human development (indicators of wellbeing), shocks (projections of future hazards such as flooding), and social-ecological conditions (indicators of determinants of resilience) [81-83]. Resilience assessment should be based on wellbeing [84], ensuring safety, and minimizing nuisances (including light pollution, noise, and vibration). Envision v3 considers these components in the subcategory "wellbeing" (six related credits) within the category quality of life. These credits are focused mostly on improving community quality of life (max. 26 points) and enhance health and safety (up to 20 points). Moreover, it should take into account poverty measures [85] following Goal 11 of European SDGs, which promotes making cities and human settlements inclusive, safe, resilient, and sustainable [9]. In this way, with social-ecological resilience, it will be able to face the unpredicted change to support human wellbeing [82]. In conclusion, assessment tools, such as RELi and Envision v3, are suitable systems to assess and predict onsite hazards, and to suggest preventative solutions, leveraging technology to identify stressors, and improving the health and wellbeing of the community and built environment.

\section{Summary and Trends of Floods, Wildfires and Seismic Hazards in EU}

As a result of human development and the growth of the built environment, floods and fires impact in term of costs and benefits on ecological and social systems. Natural seismic hazard is a result of geophysical activities, while human-induced seismicity is like floods and fires result of human development. Investing in resilience measures and disaster risk reduction needs a comprehensive comprehension of multi-hazard risk [86].

The analyzed maps (see Sections 3.3 and 3.4) of the past trends floods and wildfires show an increasing trend for floods, while, for the burnt areas, the exponential curve is slowly going down compared to the past. This means that the wildfire situation in Europe seems to have been brought under control in a better way than previously, thanks to many efforts made for guaranteeing better protection and fire preparedness. These measures have brought about a better containment of the spread of the fire, consequently reducing burnt areas. In many countries, such as Finland, for instance, more attention is being given to keeping the authorities involved in preparedness for forest fires, aware of the current situation [87]. This is mainly because poor forest management is one of the main reasons for many fires.

For enhancing the fire prevention management, the EU updated its preparedness for forest fires in 2019 with a settle up of a transition fleet for firefighting aircraft [88]. The Commission will also take into account measures regarding deforestation and forest degradation. 
On the contrary, in the last decade in Europe, many episodes of floods paralyzed cities and killed people [45]. Flooding is harder to predict and be prepared for. To better face floods, defenses and strategies are needed. That would mean thoughtfully considering the danger of building in the floodplain and planning away from these areas to reduce the risk. If this first strategy is not considered, then the flood-proof design standards must be considerably higher. Flood risk-reduction actions can be held at any stage in the disaster management process.

Generally, flood prevention measures such as structural engineering works (e.g., dikes) and nature-based measures (e.g., restoration of rivers to their natural courses) are the most common ways of reducing risk. Even if risk-reduction strategies are taken into account, it is better to be aware of the risk using software able to translate flood forecasts into flood risk-reduction actions [89]. Ecosystem conditions may increase or reduce both costs and benefits at various temporal and spatial scales. Examples of these services include sediment and nutrient deposition in floodplains and deltas and natural fire regimes that help to sustain and rejuvenate ecosystems through periodic burning.

As shown in Section 3.5, many southern European countries suffer from seismic hazards. Despite this, their buildings present structures built before the implementation required by the current seismic codes, and before the updating of the European seismic classification [90]. For this reason, after earthquakes, many buildings manifest evident damages, and consequently, significant economic losses. Even though no earthquake prediction methods are currently reliable [91] for induced seismicity, there are different approaches able to forecast the maximum magnitude of injection-induced earthquakes, as a fluid injection into geothermal reservoirs is manageable and mostly affects the regional stress fields. Accordingly, the damage level could be predicted [92]. This proves that, for facing the geohazards and avoiding unsafe buildings, it should be taken into account the assessment and mitigation of possible building structural vulnerabilities, mostly in seismic high-hazard areas (southern Europe for natural earthquakes and the rest of EU for induced ones) [90].

\section{Conclusions}

Humanity is now facing an increasing number of extreme events and economic and social issues, i.e., population growth, economic development, and rapid and often risk-blind urbanization, that place more people in harm's way. These impacts threaten human health by affecting the quality of food, water, air, and the entire variety of the environment in which we live. These impacts on different regions of the world differ considerably.

After consideration of these trends, new strategies must be considered to design new buildings and enhance the existing ones for guaranteeing a safe life for the whole population in the future.

Reducing disaster losses is vital for eliminating poverty. Still, for reaching this goal, it is necessary to be resilient and adopt tools and strategies to pursue the scope. This paper is designated for experts who are willing to build or retrofit buildings in a resilient way and may be useful for public authorities that are eager to build resilient cities as well.

Reducing disaster risk is an issue highlighted in the 2030 Agenda for Sustainable Development [93] and its global goals [9], which is supported by the United Nations Office for Disaster Risk Reduction's guidebook (UNDRR) [46], which advises local governments on developing and implementing a holistic and integrated local disaster risk reduction (DRR) and resilience strategy. It proposes a set of "Ten Essentials for Making Cities Resilient" [94]. Assessments of local disaster risk reduction strategies (DRRS) support the implementation of the "Sendai Framework for Disaster Risk Reduction 2015-2030" [95], adopted by the United Nations Member States in March 2015 in Sendai, Japan. It maps out an approach for achieving a substantial reduction in disaster losses from extreme events and a move from calamity managing to disaster risk management [24].

The comparison of these main hazards in the European countries indicated that southern Europe suffers more for seismic hazard (Italy, Greece), northern Europe for human-induced earthquakes (the Netherlands). Meanwhile, Central Europe has the flooding problem (Germany, Czech Republic, and the Netherlands). In the last decade, the droughts problem became to be extremely important 
around Europe. It is clear that every state is aware of the stressors, but not too many efforts have been taken into account to face those. An example is in Italy, where there is not a proper tool for assessing structural safety and improving the earthquakes resilience.

On the other hand, based on the literature research, analysis, and the evaluation of the tools, most of these ratings are more focused on seismic safety (earthquakes) like REDi. This means that they are not covering the other hazards like flooding problems in the proper way. The new tools should be focused not only on sustainability in general but sustainability that also covers resilience and includes some resilience criteria in the existing rating systems.

The authors are writing this paper in a situation where all the world is trying to find how to solve the coronavirus pandemic-problem, and this is about the resilience of the whole society. This is a new threat and teaches everyone that for the future, it is necessary to extend the requirements for building quality and resilience, e.g., to keep a healthy indoor environment in situations like the current one. This could be a new focus within social resilience-as resilience is influencing all the three pillars of sustainability.

Author Contributions: All authors contributed to the paper. Introduction, state of the art, methodology, result from discussion and conclusion, L.F., A.L., P.H.; Visualization, L.F.; Writing-Original Draft Preparation, L.F.; Writing, review and editing, L.F., A.L., P.H.; Supervision, A.L., P.H. All authors have read and agreed to the published version of the manuscript.

Funding: This research was funded by the Ministry of Education, Youth and Sports within the National Sustainability Programme I (NPU I), project No. LO1605-University Centre for Energy Efficient Buildings-Sustainability Phase.

Acknowledgments: We would like to thank Paolo Negro for his remarks proposed while we were preparing the manuscript. This work has been supported by the Ministry of Education, Youth and Sports within National Sustainability Programme I (NPU I), project No. LO1605-University Centre for Energy Efficient Buildings-Sustainability Phase.

Conflicts of Interest: The authors declare no conflict of interest.

\section{Nomenclature}

$\begin{array}{ll}\text { CC } & \text { Climate Change } \\ \text { DGNB } & \text { Deutsche Gesellschaft für Nachhaltiges Bauen } \\ \text { DRR } & \text { Disaster Risk Reduction } \\ \text { DDRS } & \text { Disaster Risk Reduction Strategies } \\ \text { ECMWF } & \text { European Centre for Medium-Range Weather Forecasts } \\ \text { EEA } & \text { European Environment Agency } \\ \text { EPD } & \text { Environmental Product Declaration } \\ \text { EU } & \text { European Union } \\ \text { FWI } & \text { Fire Weather Index } \\ \text { GDP } & \text { Gross domestic product } \\ \text { HI } & \text { Human-Induced } \\ \text { IPCC } & \text { Intergovernmental Panel on Climate Change } \\ \text { LCA } & \text { Life Cycle Assessment } \\ \text { LCCA } & \text { Life Cycle Cost Analysis } \\ \text { LEED } & \text { Leadership in Energy and Environmental Design } \\ \text { REDi } & \text { Resilience-based Earthquake Design Initiative } \\ \text { RESBy } & \text { Environmentally Friendly Resilient Residential Buildings } \\ \text { SDGs } & \text { Sustainable Development Goals } \\ \text { SPI } & \text { Standardized Precipitation Index } \\ \text { UCEEB } & \text { University Centre for Energy Efficient Buildings } \\ \text { UNDRR } & \text { United Nations Office for Disaster Risk Reduction }\end{array}$

\section{Appendix A}

Definition of building resilience 
Resilience is seen as the structure's ability to balance between resisting, adapting to, and recovering from extreme events. It can be further defined as consisting of the following features [96,97] for both physical and social systems:

- $\quad$ Robustness: design the structure to be more reliable in the specific situation tolerating stress without any damages or collapses; in this view, robustness is seen as part of resilience; Building parameters considered:

Columns;

Structural connections.

- Redundancy: the extent to which elements or systems that are substitutable, i.e., capable of satisfying functional requirements, degradation, or loss of functionality; Building parameters considered:

Columns;

Main water pipes into the building;

Electric and power lines.

- Resourcefulness: the capability to identify problems, establish priorities, and activate resources when conditions exist that threaten to disrupt some element, systems, or another unit of analysis; it can be further hypothesized as consisting of the capability to apply materials (such as monetary, physical, technological, and informational) and human resources to meet established priorities and reach goals; Building parameters considered:

Maintenance of building;

Memorandum of understanding between different organizations.

- The rapidity of recovery: the capacity to meet priorities and appropriately achieve goals to contain losses and avoid future disruption; Building parameters considered:

Roadways leading to the building;

Training.

\section{Appendix B}

Definition of urban resilience

1. 100 Resilient Cities: Urban Resilience is the capacity of individuals, communities, institutions, businesses, and systems within a city to survive, adapt and grow no matter what kinds of chronic stresses and acute shocks they experience [22].

2. DFID: Disaster Resilience is the ability of countries, communities, and households to manage change, by maintaining or transforming living standards in the face of shocks or stresses - such as earthquakes, drought or violent conflict-without compromising their long-term prospects [98].

3. NYC, A Stronger more resilient New York: A resilient city is one that is: first, protected by effective defences and adapted to mitigate most climate impacts; and second, able to bounce back more quickly when those defences are breached from time to time [99].

4. *New term from Global risks report, 2016: 'Resilience imperative' - an urgent necessity to find new avenues and more opportunities to mitigate, adapt to and build resilience against global risks and threats through collaboration among different stakeholders [23].

5. Resilientcity.org: A Resilient City is one that has developed capacities to help absorb future shocks and stresses to its social, economic, and technical systems and infrastructures to be still able to maintain substantially the same functions, structures, systems, and identity [100].

6. Resilience Alliance: Resilience is the capacity of a social-ecological system to absorb or withstand perturbations and other stressors such that the system remains within the same regime, mostly maintaining its structure and functions. It describes the degree to which the system is capable of self-organization, learning, and adaptation [101].

7. Rockefeller Foundation: Resilience is the capacity of individuals, communities, and systems to survive, adapt, and grow in the face of stress and shocks, and even transform when conditions require it [22].

8. UN-Habitat: Resilience refers to the ability of an urban system to withstand and to recover quickly from multiple shocks and stresses and maintain continuity of service [102].

9. USAID: Resilience is the ability of people, households, communities, countries, and systems to mitigate, adapt to and recover from shocks and stresses in a manner that reduces chronic vulnerability and facilitates inclusive growth [103].

10. World Economic Forum, Global Risk: A resilient country is "one that has the capability to

- $\quad$ adapt to changing contexts;

- withstand sudden shocks;

- $\quad$ recover to the desired equilibrium, either the previous one or a new one, while preserving the continuity of its operations." 


\section{References}

1. IPCC. Summary for Policymakers. In Global Warming of $1.5^{\circ} \mathrm{C}$. An IPCC Special Report on the Impacts of Global Warming; IPCC: Geneva, Switzerland, 2018; ISBN 9789291691517.

2. NASA Global Climate Change: Vital Signs of the Planet. Available online: https://climate.nasa.gov/ (accessed on 10 April 2020).

3. Lomba-Fernández, C.; Hernantes, J.; Labaka, L. Guide for climate-resilient cities: An urban critical infrastructures approach. Sustainability 2019, 11, 4727. [CrossRef]

4. Diaz-Sarachaga, J.M.; Jato-Espino, D. Do sustainable community rating systems address resilience? Cities 2019, 93, 62-71. [CrossRef]

5. Mallawarachchi, H.; De Silva, L.; Rameezedeen, R. Green buildings, resilience ability and the challenge of disaster risk. In Proceedings of the International Conference on Building Resilience, Ahungalla, Sri Lanka, 17-19 September 2013.

6. Wang, Y.; Du, M.; Zhou, L.; Cai, G.; Bai, Y. A novel evaluation approach of county-level city disaster resilience and urban environmental cleanliness based on SDG11 and Deqing County's situation. Sustainability 2019, 11, 5713. [CrossRef]

7. Fastenrath, S.; Coenen, L.; Davidson, K. Urban resilience in action: The resilient Melbourne strategy as transformative urban innovation policy? Sustainability 2019, 11, 693. [CrossRef]

8. UN-United Nations. The Sustainable Development Goals Report 2019; United Nations Publications: Geneva, Switzerland, 2019.

9. Siragusa, A.; Vizcaino, P.; Proietti, P.; Lavalle, C. European Handbook for SDG Voluntary Local Reviews; Publications Office of the European Union: Luxembourg, 2020; ISBN 9789276154037.

10. Ritchie, H.; Roser, M. Natural Disaster. Available online: https://ourworldindata.org/natural-disasters (accessed on 5 April 2020).

11. Sabunas, A.; Kanapickas, A. Estimation of climate change impact on energy consumption in a residential building in Kaunas, Lithuania, using HEED Software. Energy Procedia 2017, 128, 92-99. [CrossRef]

12. Jiang, A.; Liu, X.; Czarnecki, E.; Zhang, C. Hourly weather data projection due to climate change for impact assessment on building and infrastructure. Sustain. Cities Soc. 2019, 50, 101688. [CrossRef]

13. Chen, Y.; Liu, T.; Chen, R.; Zhao, M. Influence of the built environment on community flood resilience: Evidence from Nanjing City, China. Sustainability 2020, 12, 2401. [CrossRef]

14. Proag, V. The Concept of Vulnerability and Resilience. Procedia Econ. Financ. 2014, 18, 369-376. [CrossRef]

15. Kim, D.; Lim, U. Urban resilience in climate change adaptation: A conceptual framework. Sustainability 2016, 8, 405. [CrossRef]

16. USGBC. RELi 2.0 Rating Guidelines for Resilient Design + Construction; U.S. Green Building Council: Washington, DC, USA, 2018.

17. Institute for Sustainable Infrastructure. ENVISION V3: What You Need to Know. 2018. Available online: https://sustainableinfrastructure.org/wp-content/uploads/ENVISION-V3-Need-to-Know-and-FAQ. pdf (accessed on 15 February 2020).

18. Almufti, I.; Willford, $M$. The REDi ${ }^{\mathrm{TM}}$ rating system: A framework to implement resilience-based earthquake design for new buildings. In Proceedings of the 10th US National Conference on Earthquake Engineering, Frontiers of Earthquake Engineering, Anchorage, AK, USA, 21-25 July 2014. [CrossRef]

19. University Centre for Energy Efficient Building (UCEEB). RESBY-Environmentally Friendly Resilient Residential Buildings. 2017. Available online: https:/www.uceeb.cz/en/projects/resby-environmentallyfriendly-resilient-residential-buildings (accessed on 10 February 2020).

20. Bichai, F.; Ashbolt, N. Public health and water quality management in low-exposure stormwater schemes: A critical review of regulatory frameworks and path forward. Sustain. Cities Soc. 2017, 28, 453-465. [CrossRef]

21. Rus, K.; Kilar, V.; Koren, D. Resilience assessment of complex urban systems to natural disasters: A new literature review. Int. J. Disaster Risk Reduct. 2018, 31, 311-330. [CrossRef]

22. The Rockefeller Foundation. 100 Resilient Cities. Available online: https://www.rockefellerfoundation.org/ 100-resilient-cities/ (accessed on 20 March 2020).

23. World Economic Forum. Global Risks Report 2019; World Economic Forum: Geneva, Switzerland, 2019; ISBN 9781944835156. 
24. Wallemacq, P. Economic Losses, Poverty and Disasters 1998-2017; United Nations Office for Disaster Risk Reduction: Geneva, Switzerland, 2018.

25. European Environmental Agency (EEA). Economic Losses from Climate-Related Extremes in Europe. Available online: https://www.eea.europa.eu/data-and-maps/indicators/direct-losses-from-weatherdisasters-3/assessment-2 (accessed on 5 February 2020).

26. Harrison, C.G.; Williams, P.R. A systems approach to natural disaster resilience. Simul. Model. Pract. Theory 2016, 65, 11-31. [CrossRef] [PubMed]

27. Moura Rezende, O.; Ribeiro da Cruz de Franco, A.B.; de Oliveira, A.K.B.; Pitzer Jacob, A.C.; Gomes Miguez, M. A framework to introduce urban flood resilience into the design of flood control alternatives. J. Hydrol. 2019, 576, 478-493. [CrossRef]

28. Schewe, J.; Heinke, D.; Gerten, I.; Haddeland, N.W.; Arnell, D.B. Multimodel assessment of water scarcity under climate change. Proc. Natl. Acad. Sci. USA 2014, 111, 3245-3250. [CrossRef]

29. Pender, G.; Neelz, S. Use of computer models of flood inundation to facilitate communication in flood risk management. Environ. Hazards 2007, 7, 106-114. [CrossRef]

30. Faber, R. Flood Risk Analysis: Residual Risks and Uncertainties in an Austrian Context; University of Natural Resources and Applied Life Sciences: Vienna, Austria, 2006.

31. Arnbjerg-Nielsen, K.; Fleischer, H. Feasible adaptation strategies for increased risk of flooding in cities due to climate change. Water Sci. Technol. 2009, 60, 273-281. [CrossRef]

32. Fridell, K.; Thynell, A.; Bruhn, F.; Fors, J.; Sixtensson, S.; Vysoký, M. Livable Streets—A Handbook of Bluegreengrey Systems Version 2.0; Edge: Malmö, Sweden, 2020.

33. European Environmental Agency (EEA). Urban Areas at Risk of River Flooding. Available online: https: //www.eea.europa.eu/data-and-maps/figures/share-of-the-citys-urban-1 (accessed on 5 February 2020).

34. European Environmental Agency (EEA). River Floods. Available online: https://www.eea.europa.eu/dataand-maps/indicators/river-floods-3/assessment (accessed on 5 February 2020).

35. IPCC. Global WARMING of $1.5^{\circ} \mathrm{C}$. An IPCC Special Report on the Impacts of Global WARMING of $1.5^{\circ} \mathrm{C}$ above Pre-Industrial Levels and Related Global Greenhouse Gas Emission Pathways, in the Context of Strengthening the Global Response to the Threat of Cli; IPCC: Geneva, Switzerland, 2018; Volume 291.

36. Blöschl, G.; Kiss, A.; Viglione, A.; Barriendos, M.; Böhm, O.; Brázdil, R.; Coeur, D.; Demarée, G.; Llasat, M.C.; Macdonald, N.; et al. Current European flood-rich period exceptional compared with past 500 years. Nature 2020, 583, 560-566. [CrossRef]

37. San-Miguel-Ayanz, J.; Schulte, E.; Schmuck, G.; Camia, A.; Strobl, P.; Liberta, G.; Giovando, C.; Boca, R.; Sedano, F.; Kempeneers, P.; et al. Comprehensive Monitoring of Wildfires in Europe: The European Forest Fire Information System (EFFIS). Approaches Manag. Disaster Assess. Hazards Emerg. Disaster Impacts 2012. [CrossRef]

38. Van Wagner, C.E. Development and Structure of the Canadian Forest Fire Weather Index System; Canadian Forestry Service: Ottawa, ON, Canada, 1987.

39. Venäläinen, A.; Korhonen, N.; Hyvärinen, O.; Koutsias, N.; Xystrakis, F.; Urbieta, I.R.; Moreno, J.M. Temporal variations and change in forest fire danger in Europe for 1960-2012. Nat. Hazards Earth Syst. Sci. 2014, 14, 1477-1490. [CrossRef]

40. Wu, M.; Knorr, W.; Thonicke, K.; Schurgers, G.; Camia, A.; Arneth, A. Sensitivity of burned area in Europe to climate change, atmospheric $\mathrm{CO} 2$ levels, and demography: A comparison of two fire-vegetation models. J. Geophys. Res. Biogeosci. 2015, 120, 2256-2272. [CrossRef]

41. Joint Research Centre (JRC). Forest Fire Danger Extremes in Europe under Climate Change: Variability and Uncertainty; Publications Office of the European Union: Luxembourg, 2018.

42. European Commission. Copernicus Programme. Available online: https://www.copernicus.eu (accessed on 31 August 2020).

43. Khabarov, N.; Krasovskii, A.; Obersteiner, M.; Swart, R.; Dosio, A.; San-Miguel-Ayanz, J.; Durrant, T.; Camia, A.; Migliavacca, M. Forest fires and adaptation options in Europe. Reg. Environ. Chang. 2016, 16, 21-30. [CrossRef]

44. Turco, M.; Rosa-Cánovas, J.J.; Bedia, J.; Jerez, S.; Montavez, J.P.; Llsat, M.C.; Provenzale, A. Exacerbated fires in Mediterranean Europe due to anthropogenic warming projected with non-stationary climate-fire models. Nat. Commun. 2018, 9, 1-9. [CrossRef] [PubMed] 
45. European Commission. Forest Fires in Europe, Middle East and North Africa 2018; European Commission: Brussels, Belgium, 2018.

46. United Nations. United Nations Office for Disaster Risk Reduction-2018 Annual Report; United Nations Publications: Geneva, Switzerland, 2019.

47. Turco, M.; Bedia, J.; Di Liberto, F.; Von Hardenberg, J.; Koutsias, N. Decreasing fires in Mediterranean Europe. PLoS ONE 2016, 11, e0150663. [CrossRef]

48. European Environmental Agency (EEA). Climate Change, Impacts and Vulnerability in Europe 2016; Publications Office of the European Union: Luxembourg, 2017.

49. Tornaghi, M.L.; Loli, A.; Negro, P. Balanced Evaluation of Building Design. Buildings 2018, 8, 52. [CrossRef]

50. Sikder, S.K.; Asadzadeh, A.; Kuusaana, E.D.; Mallik, B.; Kotter, T. Stakeholders partecipation for urban climate resilience: A case of informal settlements regularization in Khulna city, Bangladesh. J. Urban Reg. Anal. 2015, 7, 5-20.

51. Romano, E.; Negro, P.; Taucer, F. Seismic Performance Assessment Addressing Sustainability and Energy Efficiency; European Commission: Brussels, Belgium, 2014.

52. The Human-Induced Earthquake Database (HiQuake). Available online: https://inducedearthquakes.org/ (accessed on 30 January 2020).

53. Reed, S.; Earthquakes Are Jolting the Netherlands. Gas Drilling Is to Blame. Available online: https: //www.nytimes.com/2019/10/24/business/energy-environment/netherlands-gas-earthquakes.html (accessed on 1 February 2020).

54. Valagussa, A.; Marc, O.; Frattini, P.; Crosta, G.B. Seismic and geological controls on earthquake-induced landslide size. Earth Planet. Sci. Lett. 2019, 506, 268-281. [CrossRef]

55. Wang, P.; Zhao, M.; Du, X.; Cheng, X. A finite element solution of earthquake-induced hydrodynamic forces and wave forces on multiple circular cylinders. Ocean Eng. 2019, 189, 106336. [CrossRef]

56. EarthDate Human-Induced Earthquakes. Available online: https://www.earthdate.org/human-inducedearthquakes (accessed on 1 February 2020).

57. Sellberg, M.M.; Borgström, S.T.; Norström, A.V.; Peterson, G.D. Improving participatory resilience assessment by cross-fertilizing the Resilience Alliance and Transition Movement approaches. Ecol. Soc. 2017, $22,28$. [CrossRef]

58. Nan, C.; Sansavini, G. A quantitative method for assessing resilience of interdependent infrastructures. Reliab. Eng. Syst. Saf. 2017, 157, 35-53. [CrossRef]

59. Smart Mature Resilience. European Resilience Management Guideline; Tecnun: Donostia, Spain, 2018; Available online: https://smr-project.eu/fileadmin/user_upload/Documents/Resources/WP_5/SMR-EMRG-handbookWWW_s.pdf (accessed on 1 June 2020).

60. Smart Mature Resilience. Risk Systemicity Questionnaire User Manual; Tecnun: Donostia, Spain, 2018; Available online: https://smr-project.eu/fileadmin/user_upload/Documents/Resources/WP_3/SMR-RSQmanual-WWW.compressed.pdf (accessed on 1 June 2020).

61. Smart Mature Resilience. Resilience Maturity Model; Tecnun: Donostia, Spain, 2018; Available online: https://smr-project.eu/tools/maturity-model-guide/ (accessed on 1 June 2020).

62. Smart Mature Resilience. Resilience Maturity Model Handbook; Tecnun: Donostia, Spain, 2018; Available online: https://smr-project.eu/fileadmin/user_upload/Documents/Resources/WP_7/SMR-A1-www.pdf (accessed on 1 June 2020).

63. BREEAM. BREEAM UK New Construction 2018 Scheme Assessment Timeline; BRE Global Ltd.: Watford, UK, 2018; Available online: https://www.bregroup.com/brebreeam/wp-content/uploads/sites/3/2018/08/GN37_ BREEAM_UK_New_Construction_2018_Scheme_Assessment_Timeline_v1.0.pdf (accessed on 15 April 2020).

64. DGNB. DGNB System Criteria Set New Construction Building; DGNB: Stuttgart, Germany, 2018.

65. iiSBE Italia. Protocollo ITACA Nazionale; iiSBE Italia: Rome, Italy, 2012.

66. USGBC. LEED Rating Systems; USGBC: Washigton, DC, USA; Available online: https://www.usgbc.org/leed (accessed on 16 April 2020).

67. Roostaie, S.; Nawari, N.; Kibert, C.J. Integrated sustainability and resilience assessment framework: From theory to practice. J. Clean. Prod. 2019, 232, 1158-1166. [CrossRef]

68. Architecture 20302030 Palette. Available online: https://architecture2030.org/2030-palette/ (accessed on 20 April 2020). 
69. USGBC. Introducing the USGBC's New RELi Resilience Rating System. Available online: https://www.usgbc. org/education/sessions/blc-2018/introducing-usgbcs-new-reli-resilience-rating-system-11685252 (accessed on 12 April 2020).

70. National Fire Protection Association. NFPA 1144 Standard for Reducing Structure Ignition Hazards from Wildland Fire. 2018. Available online: https://www.nfpa.org/codes-and-standards/all-codes-and-standards/ list-of-codes-and-standards/detail?code=1144 (accessed on 2 June 2020).

71. Institute for Sustainable Infrastructure. Envision Sustainable Infrastructure Framework Version 3; Institute for Sustainable Infrastructure: Washington, DC, USA, 2018.

72. Trop, T. Using Envision ${ }^{\mathrm{TM}}$ rating tool to assess the sustainability of public bike sharing systems: A case study of the Tel-O-Fun project in Tel Aviv-Yafo. Sustain. Cities Soc. 2018, 40, 704-712. [CrossRef]

73. Almufti, I.; Willford, M.; Delucchi, M.; Davis, C.; Hanson, B.; Langdon, D.; Friedman, D.; Johnson, L.; Nielsen, G.; Riordan, N.O.; et al. REDi ${ }^{T M}$ Rating System; ARUP: San Francisco, CA, USA, 2013; Available online: https://www.arup.com/perspectives/publications/research/section/redi-rating-system (accessed on 3 April 2020).

74. Almufti, I.; Willford, M.; Delucchi, M.; Davis, C.; Hanson, B.; Langdon, D.; Friedman, D.; Johnson, L.; Nielsen, G.; Riordan, N.O.; et al. REDi ${ }^{T M}$ Rating System Resilience-based Earthquake Design Initiative for the Next Generation of Buildings; ARUP: San Francisco, CA, USA, 2014; pp. 1-133.

75. Lupíšek, A.; Růžička, J.; Tywoniak, J.; Hájek, P.; Volf, M. Criteria for evaluation of resilience of residential buildings in central Europe. Int. Rev. Appl. Sci. Eng. 2018, 9, 89-93. [CrossRef]

76. UCEEB. Resilient Apartment Buildings. Criteria for the Evaluation of Apartment Buildings from the Point of View of Resilience, Mitigation of Climate Change and Adaptation to Climate Change; UCEEB: Buštěhrad, Czech Republic, 2018.

77. RIBA. RIBA Plan of Work. Available online: https://www.architecture.com/knowledge-and-resources/ resources-landing-page/riba-plan-of-work (accessed on 25 June 2020).

78. USGBC. LEED v4 for Building Design and Construction; USGBC: Washington, DC, USA, 2019; Available online: https://www.usgbc.org/sites/default/files/LEED\%20v4\%20BDC_07.25.19_current.pdf (accessed on 16 April 2020).

79. DGNB. DGNB System New Construction Buildings Criteria Set; DGNB: Stuttgart, Germany, 2020.

80. Moraci, F.; Errigo, M.F.; Fazia, C.; Burgio, G.; Foresta, S. Making less vulnerable cities: Resilience as a new paradigm of smart planning. Sustainability 2018, 10, 755. [CrossRef]

81. Walker, B.; Holling, C.S.; Carpenter, S.R.; Kinzig, A. Resilience, Adaptability and Transformability in Social-ecological Systems. Ecol. Soc. 2004, 9. [CrossRef]

82. Folke, C.; Carpenter, S.R.; Walker, B.; Scheffer, M.; Chapin, T.; Rockström, J. Resilience thinking: Integrating resilience, adaptability and transformability. Ecol. Soc. 2010, 15, 43. [CrossRef]

83. Folke, C.; Biggs, R.; Norström, A.V.; Reyers, B.; Rockström, J. Social-ecological resilience and biosphere-based sustainability science. Ecol. Soc. 2016, 21, 41. [CrossRef]

84. Barrett, C.B.; Constas, M.A. Toward a theory of resilience for international development applications. Proc. Natl. Acad. Sci. USA 2014, 111, 14625-14630. [CrossRef]

85. Bousquet, F.; Botta, A.; Alinovi, L.; Barreteau, O.; Bossio, D.; Brown, K.; Caron, P.; Cury, P.; D’Errico, M.; DeClerck, F.; et al. Resilience and development: Mobilizing for transformation. Ecol. Soc. 2016, $21,40$. [CrossRef]

86. Dabbeek, J.; Silva, V.; Galasso, C.; Smith, A. Probabilistic earthquake and flood loss assessment in the Middle East. Int. J. Disaster Risk Reduct. 2020, 49, 101662. [CrossRef]

87. Finnish Forest Association. Forest.fi. Available online: https://forest.fi (accessed on 31 August 2020).

88. European Commission. rescEU: EU Establishes Initial Firefighting Fleet for Next Forest Fire Season. Available online: https://www.pubaffairsbruxelles.eu/resceu-eu-establishes-initial-firefighting-fleet-for-next-forestfire-season-eu-commission-press/ (accessed on 31 August 2020).

89. Bischiniotis, K.; de Moel, H.; van den Homberg, M.; Couasnon, A.; Aerts, J.; Guimarães Nobre, G.; Zsoter, E.; van den Hurk, B. A framework for comparing permanent and forecast-based flood risk-reduction strategies. Sci. Total Environ. 2020, 720. [CrossRef]

90. Belleri, A.; Marini, A. Does seismic risk affect the environmental impact of existing buildings? Energy Build. 2016, 110, 149-158. [CrossRef] 
91. Foulger, G.R.; Wilson, M.P.; Gluyas, J.G.; Julian, B.R.; Davies, R.J. Earth-Science Reviews Global review of human-induced earthquakes. Earth Sci. Rev. 2018, 178, 438-514. [CrossRef]

92. Rathnaweera, T.D.; Wu, W.; Ji, Y.; Gamage, R.P. Understanding injection-induced seismicity in enhanced geothermal systems: From the coupled thermo-hydro-mechanical-chemical process to anthropogenic earthquake prediction. Earth Sci. Rev. 2020, 205, 103182. [CrossRef]

93. United Nations. Transforming Our World: The 2030 Agenda for Sustainable Development; United Nations Publications: Geneva, Switzerland, 2016.

94. UNDRR. The Ten Essentials for Making Cities Resilient. Available online: https://www.unisdr.org/campaign/ resilientcities/toolkit/article/the-ten-essentials-for-making-cities-resilient (accessed on 25 May 2020).

95. United Nations. Sendai Framework for Disaster Risk Reduction 2015-2030; United Nations Publications: Geneva, Switzerland, 2009.

96. Bruneau, M.; Chang, S.E.; Eguchi, R.T.; Lee, G.C.; O’Rourke, T.D.; Reinhorn, A.M.; Shinozuka, M.; Tierney, K.; Wallace, W.A.; Von Winterfeldt, D. A Framework to Quantitatively Assess and Enhance the Seismic Resilience of Communities. Earthq. Spectra 2003, 19, 733-752. [CrossRef]

97. Devès, M.H.; Lang, M.; Bourrelier, P.H.; Valérian, F. Why the IPCC should evolve in response to the UNFCCC bottom-up strategy adopted in Paris? An opinion from the French Association for Disaster Risk Reduction. Environ. Sci. Policy 2017, 78, 142-148. [CrossRef]

98. Dfid. Defining Disaster Resilience: A DFID Approach Paper; Department for International Development: London, UK, 2011.

99. The City of New York. A Stronger, More Resilient New York; City of New York: New York, NY, USA, 2013.

100. Post Carbon Institute. Resilience. Available online: https://www.resilience.org/ (accessed on 30 May 2020).

101. Resilience Alliance Resilience. Available online: https://www.resalliance.org/ (accessed on 30 May 2020).

102. Urban Resilient Hub. Divergent Definitions_Embracing a Holistic Understanding of Urban Resilience; Urban Resilient Hub: Barcelona, Spain, 2018; Available online: https://urbanresiliencehub.org/article/understandingurban-resilience/ (accessed on 30 May 2020).

103. USAID. Building Resilience to Recurrent Crisis-USAID Policy and Program Guidance. 2012. Available online: https:/www.usaid.gov/sites/default/files/documents/1866/Policy $\% 20 \% 26 \% 20$ Program\% 20Guidance\%20-\%20Building\%20Resilience\%20to\%20Recurrent\%20Crisis_Dec\%202012.pdf (accessed on 1 June 2020).

(C) 2020 by the authors. Licensee MDPI, Basel, Switzerland. This article is an open access article distributed under the terms and conditions of the Creative Commons Attribution (CC BY) license (http://creativecommons.org/licenses/by/4.0/). 